\title{
Evaluation of Greenland Ice Sheet Surface Climate in the HIRHAM Regional Climate Model Using Automatic Weather Station Data
}

\author{
JASON E. BOX \\ Byrd Polar Research Center, The Ohio State University, Columbus, Ohio \\ ANNETTE RinKe \\ Alfred Wegener Institute for Polar and Marine Research, Potsdam, Germany
}

(Manuscript received 3 January 2002, in final form 20 September 2002)

\begin{abstract}
The 1998 annual cycle and 1991-98 summer simulations of Greenland ice sheet surface climate are made with the $0.5^{\circ}$-horizontal resolution HIRHAM regional climate model of the Arctic. The model output is compared with meteorological and energy balance observations from 15 Greenland Climate Network automatic weather stations. The model reproduces the monthly average surface climate parameters, to a large extent within model and observational uncertainty. However, certain systematic model biases were identified, caused in particular by inaccurate GTOPO30 elevation data over Greenland, $180 \mathrm{~m}$ lower on average, with errors as large as -840 $\mathrm{m}$ over $50-\mathrm{km}$ grid cells. The resulting warm biases enhance a negative albedo bias, which in turn leads to positive net shortwave radiation biases. Surface sensible and latent heat fluxes are overestimated, apparently due to model warm bias and $100 \%$ greater than observed wind speeds. Interannual variability in temperature and albedo are smaller in the model than in the observations, while the opposite is evident for incoming shortwave radiation and wind speed. Annual maps and total mass fluxes of precipitation and evaporation are compared with results from other studies. Based on the results of a multiparameter comparison, solid recommendations for improved regional models of ice sheet climate are made.
\end{abstract}

\section{Introduction}

\section{a. General motivation}

Regional models have the potential to be used as smart interpolators, yielding useful data for a wide range of times and locations not supported by in situ observations. This is particularly the case for the polar regions, where observation sites are fewer. As regional climate model precision and accuracy are enhanced, they become valuable tools for glaciological research. A prime application in glaciology is to investigate continental ice sheet mass balance changes. Determining ice sheet climate is important because major changes in ice sheet dimensions affect climate and sea level throughout the world. Global climate models have been used to estimate parameters or changes in Greenland ice sheet mass balance (Ohmura et al. 1996; Thompson and Pollard 1997; Ohmura et al. 1999). However, confidence can be taken in the results of climate change experiments only if the model produces a good simulation of the present climate (Walsh et al. 2002). The

Corresponding author address: Dr. Jason E. Box, Byrd Polar Research Center, The Ohio State University, 1090 Carmack Road, Scott Hall Room 108, Columbus, OH 43210-1002.

E-mail: box.11@osu.edu horizontal resolution of the global models is still relatively coarse, therefore the technique of nested limitedarea (or regional) climate models (RCMs) is a promising way to provide finer-scale climate information. Additionally, the RCMs give insights into the atmospheric processes that are responsible for the distribution and variability of the regional climate.

Evaluation of regional models is on the one hand a prerequisite before they can be used for the proposed glaciological application, but on the other hand it is important because it should yield recommendations for model development. The application and validation of a RCM over the Greenland ice sheet, with its homogeneous surface and extreme meteorological conditions, is a very good "laboratory" for testing the model parameterizations.

Much recent work has gone into the validation of RCM simulations over the Greenland ice sheet (Bromwich et al. 2001a; Klein et al. 2001; Cassano et al. 2001) and of observational data analyses (Hanna and Valdes 2001). Their results indicate the importance of accurate representation of momentum exchange in the surface boundary, surface albedo, cloud-radiation interactions, and model topography. Elevation errors have been linked with inaccuracies in precipitation fields over 
Greenland (Bromwich et al. 2001b). The RCM used in this study is called HIRHAM and is state of the art, well validated, and widely used for various climate applications (Dethloff et al. 1996; Christensen et al. 1998; Haugen et al. 1999; van Lipzig et al. 1999; Christensen and Kuhry 2000; Pan et al. 2000; Rinke et al. 2000). The acronym HIRHAM comes from the combination of HIRLAM and ECHAM4, indicating that HIRHAM was built from the dynamics of HIRLAM (High Resolution Limited Area Model), used in Scandinavian countries for weather forecasts and from the physical parameterizations of ECHAM4, the global circulation model from the Max Planck Institute for Meteorology in Hamburg which has its roots in the European Centre for MediumRange Weather Forecasts (ECMWF) model.

Our aim during the comparison of HIRHAM-simulated Greenland surface climate with data collected by a network of automatic weather stations is to answer a basic question that may offer insight into model performance. The primary questions is: Is there a consistent model bias over the annual cycle and/or interannually? Physically meaningful reasons for model biases are discussed and, if possible, model development recommendations are made.

\section{b. The Greenland ice sheet}

The Greenland ice sheet is by far the largest orographic feature in the Arctic and is huge compared with other glaciers in the world, except Antarctica. Greenland is $82 \%$ covered by a single ice sheet, $1.736 \times 10^{6} \mathrm{~km}^{2}$ in area. The ice sheet assumes the form of a dome rising to an elevation of $3255 \mathrm{~m}$ (Bamber et al. 2001; Fig. 1). Greenland is situated in the path of atmospheric planetary wave circulation and due to its high elevation greatly influences Northern Hemisphere atmospheric circulation (Barry and Kiladis 1982). A global circulation model sensitivity study in which the Greenland orography is doubled, halved, and removed, indicates the importance of the Greenland orography in anchoring planetary circulation (Kristjánsson and McInnes 1999), particularly the location of the Icelandic low, the North Atlantic's dominant storm center.

Recent results indicate that Greenland's contribution to sea level change was substantially greater than Antarctica during the last climatic optimum, about $125 \mathrm{kyr}$ before present (Cuffey and Marshall 2000). The current contribution of Greenland ice sheet mass balance to sea level change is unknown, but is expected to be on the order of the current observed sea level change (Reeh 1999). Understanding the influence of the Greenland ice sheet on hemispheric-scale climate is pivotal in the context of abrupt climate change, potentially influenced by anthropogenic forcing. Thus, the accurate representation of Greenland in climate simulations is of crucial importance in climatology.

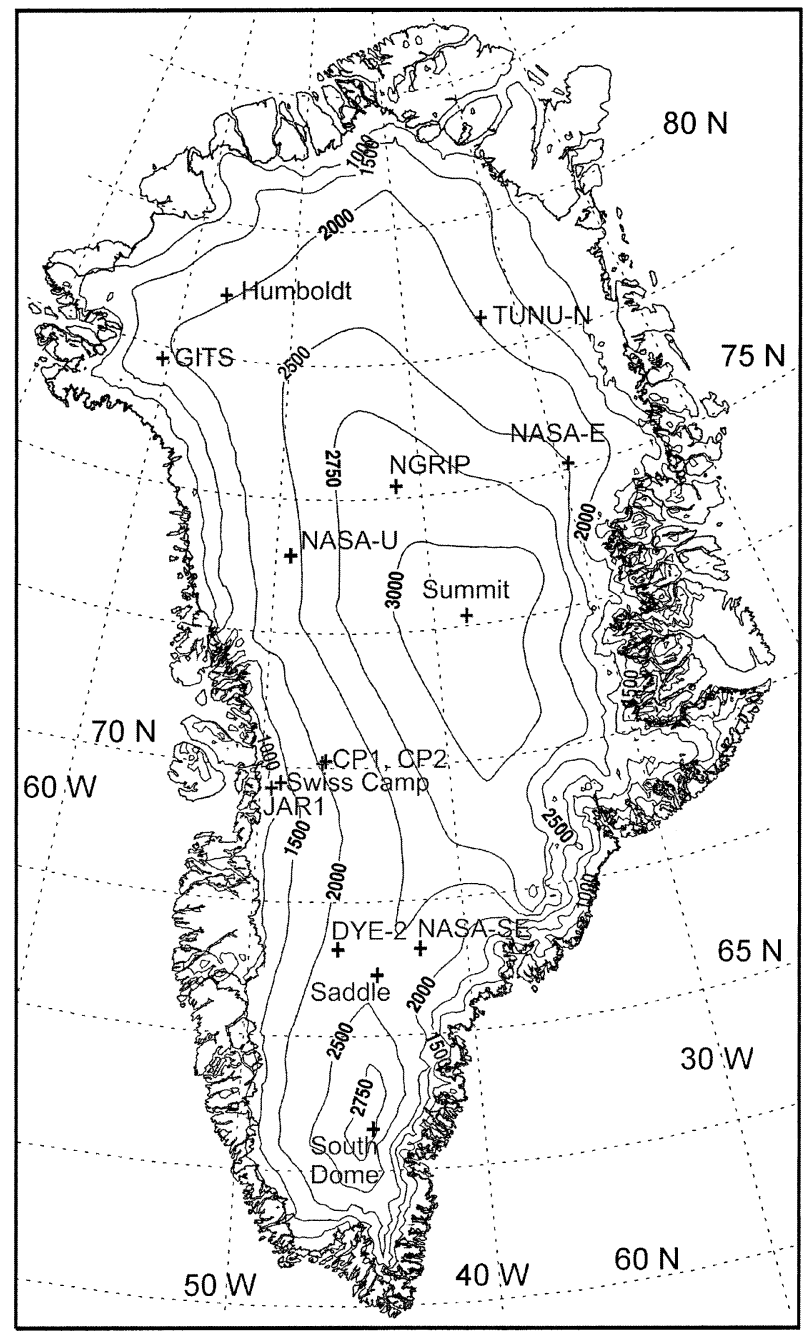

FIG. 1. Greenland map featuring the inland ice region and Greenland Climate Network (GC-Net) locations.

\section{Data and simulations}

\section{a. Observational data}

The primary observational dataset used in this study is collected by a network of automatic weather stations (AWS) distributed widely over the surface of the Greenland ice sheet (Fig. 1). As of June 2000, this Greenland Climate Network (GC-Net) consisted of 20 AWSs (Steffen et al. 1996; Steffen and Box 2001). See these references for station coordinates. Beginning in 1995, one to five AWS were installed during successive annual expeditions, while older sites were maintained. Data from the 15 GC-Net sites shown in Fig. 1 are used in this study. Data from five sites span 1995-98. Observational data from Swiss Camp that are used in this study span 1991-98. Measurements at Swiss Camp prior to 1995 were initiated by Swiss Federal Institute of Technology (ETH) expeditions (Ohmura et al. 1991, 1992) and maintained by K. Steffen (2001, personal 
TABLE 1. GC-Net instruments used in this study.

\begin{tabular}{|c|c|c|c|}
\hline Parameter & Instrument & $\begin{array}{l}\text { Sampling } \\
\text { interval }\end{array}$ & $\begin{array}{l}\text { Estimated } \\
\text { monthly } \\
\text { uncertainty }\end{array}$ \\
\hline Air temperature & $\begin{array}{l}\text { Type-E } \\
\text { thermocouple }\end{array}$ & $60 \mathrm{~s}$ & $0.02 \mathrm{~K}$ \\
\hline Station pressure & Vaisala PTB101B & $60 \mathrm{~min}$ & $<0.1 \mathrm{hPa}$ \\
\hline Wind speed and direction & RM Young 05103 & $60 \mathrm{~s}$ & $0.1 \mathrm{~m} \mathrm{~s}^{-1}$ \\
\hline $\begin{array}{l}\text { Incoming and reflected } \\
\text { solar radiation }\end{array}$ & LI-COR Photodiode & $15 \mathrm{~s}$ & $5 \mathrm{~W} \mathrm{~m}^{-2}$ \\
\hline Net radiation & REBS Q*7 & $15 \mathrm{~s}$ & $10 \mathrm{~W} \mathrm{~m}^{-2}$ \\
\hline Surface height change & Campbell Sci. SR-50 & $10 \mathrm{~min}$ & $1 \mathrm{~cm}$ \\
\hline
\end{tabular}

communication). In the time period covered by this study, the majority of GC-Net AWS were located in the accumulation zone near or above 2000-m elevation. The Swiss Camp and JAR1 sites represent the ablation zone, where substantial summer melting of $>1 \mathrm{~m}$ is observed. Additional temperature data from Summit, spanning 1987-99 have been compiled by Shuman et al. (2001). This compilation represents the merging of 1987-96 University of Wisconsin AWS data (Stearns and Weidner 1991) with 1996-99 GC-Net data, with a few data gaps supplemented by daily mean temperature derived from passive microwave. Thus, two sites with up to 8 $\mathrm{yr}$ of data for interannual analysis of temperature are included here. The 1991-98 Swiss Camp record also includes solar and net radiation fluxes and wind measurements.

Statistical procedures are applied to the hourly GCNet time series in effort to remove occasional spurious data values (Steffen and Box 2001). The data that are rejected by these filters represent less than $5 \%$ of the total data volume. Quality control is refined by iterations consisting of human inspection followed by a set of algorithms tuned until all obviously spurious data are removed. Missing data are interpolated linearly if within a prescribed autocorrelation threshold. Monthly and annual means are analyzed, not hourly data. Thus, the effect of occasional persistent spurious data values is greatly minimized.

Seven measured parameters are compared with the HIRHAM model output. These are temperature; wind speed and direction; incoming and reflected solar irradiance; net radiation flux over visible and infrared wavelengths; and station barometric pressure (Table 1). Parameters derived from the direct measurements are 2$\mathrm{m}$ air temperature, albedo, net infrared flux, and turbulent fluxes. Further description of observational data is given in the following.

\section{1) Two-METER AIR TEMPERATURE}

Temperature at a constant height of $2 \mathrm{~m}$ is calculated using the observed monthly mean temperature at two levels, instrument heights, and linear interpolation. Instrument heights are calculated using the initial instrument height upon installation and subsequent surface height change measured by acoustic height sensors. Instrument height error has been checked during site revisits to be within $5 \mathrm{~cm}$. The median heights of GCNet temperature sensors were 1.4 and $2.6 \mathrm{~m}$, respectively. Absolute uncertainty of monthly mean $2-\mathrm{m}$ temperature is within $1 \mathrm{~K}$.

\section{2) TEN-METER Wind SPEED AND DIRECTION}

A logarithmic wind profile is fit through the observations to estimate $10-\mathrm{m}$ wind speeds for comparison with HIRHAM 10-m winds. In cases when data from only one measurement level are available, a logarithmic profile is assumed with a roughness length value of 0.5 $\mathrm{mm}$. No stability correction is applied to the $10-\mathrm{m}$ wind data, as stability effects should be implicit in the wind speed profile measurements. The uncertainty in the AWS wind speed and wind direction observations are approximately $0.1 \mathrm{~m} \mathrm{~s}^{-1}$ and $10^{\circ}$, respectively. Wind direction data are expressed in degrees from the north. Thus, $90^{\circ}$ represents an easterly wind.

\section{3) Shortwave Radiation data}

The GC-Net sites employ a LI-COR 200SZ photoelectric diode to measure incoming and reflected solar radiation in the $400-1100-\mathrm{nm}$ wavelength range. The peak response of this pyranometer occurs at $950 \mathrm{~nm}$. LI-COR reflected shortwave (SW) radiation measurements over snow exhibit a positive bias of about $4 \%$. This positive bias in GC-Net reflected shortwave is corrected in this study by applying an offset of $-4 \%$ to reflected radiation data based on clear-sky calibrations with Eppley Precision Spectral Pyranometer observations at Swiss Camp. At some sites in 1998 (Tunu-N, NGRIP, NASA-E, and Humboldt), springtime frost on shortwave sensors leads to spuriously low incoming shortwave values. March 1998 monthly means are omitted from these sites. Additionally, April 1998 data are removed for NASA-E. Shortwave radiation data uncertainty generally increases with increasing zenith angle. Instrument level has also been observed to drift. Combining these uncertainties, the absolute shortwave radiation observation uncertainty is within $10 \%$ for monthly means. 


\section{4) Net RAdiation data}

GC-Net net radiation observations are made by the Radiation and Energy Balance Systems (REBS) Q*7 instrument. REBS measurements on GC-Net AWS are not ventilated. However, unless ventilated, REBS measurements have been found to be susceptible to large errors, particularly in winter, for sites above $1200 \mathrm{~m}$ due to frost growth within and on the radiometer domes. Wintertime net radiation measurements for high-elevation sites indicate values very near zero, while negative values are expected. Domeless Kipp and Zonen NR-Lite net radiometers have been installed at Swiss Camp and Summit in 1999. Monthly average net radiation data from Summit in winter are now significantly lower. However, at this stage in the quality control and correction phase of data processing, only net radiation records from Swiss Camp and JAR 1 are believed to be reliable throughout the year. Thus, the net radiation comparison in this study is limited to these two lowelevation sites. Uncertainty for these data are believed to be within $15 \%$ for monthly means.

\section{5) Turbulent HeAt FluXes}

Turbulent heat fluxes of sensible $\left(Q_{H}\right)$ and latent heat $\left(Q_{E}\right)$ are important components of the surface energy balance. The value $Q_{H}$ indicates the convective exchange of heat between the surface and atmosphere. The value $Q_{E}$ indicates the magnitude of sublimation or evaporation and the associated latent heat exchange from water vapor phase changes. The values $Q_{H}$ and $Q_{E}$ are available from both HIRHAM output and from aerodynamic profile calculations applied to the in situ GCNet data. In situ $Q_{H}$ is calculated based on the GC-Net vertical temperature profile data following the procedure in Steffen and deMaria (1996). The value $Q_{E}$ is calculated and validated in comparison with eddy correlation and snow lysimeters after Box and Steffen (2001). The sign convention followed is with reference to the surface. Thus, negative $Q_{E}\left(Q_{H}\right)$ indicates of net water vapor (heat) deposition from the atmosphere to the surface, respectively.

\section{b. Model description}

The model employed in this study is called HIRHAM (Christensen et al. 1996) and has been applied to a variety of Arctic climate studies (recently, Dethloff et al. 2001, 2002; Rinke et al. 1999a,b, 2000; Rinke and Dethloff 2000; Christensen and Kuhry 2000; Dorn et al. 2000; Kiilsholm et al. 2002, manuscript submitted to Geophys. Res. Lett.). The integration domain used in the present study covers the whole Arctic basin north of $60^{\circ} \mathrm{N}$ with $110 \times 100$ grid points and a horizontal resolution of $0.5^{\circ}$. The vertical discretization consists of 19 irregularly spaced levels in hybrid sigma- $p$ coordinates from the surface up to $10 \mathrm{hPa}$ with five vertical layers in the lowest $1500 \mathrm{~m}$. Besides the surface, the lowest model level is about $30 \mathrm{~m}$. The model is forced at the lateral boundaries using temperature, wind, humidity, and surface pressure (updated every $6 \mathrm{~h}$ ) and at the lower boundary using sea surface temperature and sea ice fraction (updated daily) provided from observational analyses from the European Centre for Medium-Range Weather Forecasts. HIRHAM uses the physical parameterization package of the general circulation model ECHAM4 (Roeckner et al. 1996) which includes radiation, convection, clouds, land surface processes, planetary boundary layer (PBL) processes, horizontal diffusion, and gravity wave drag. Short- and longwave radiative fluxes are calculated using the model-predicted cloud water content. The importance of calculating radiative fluxes in this manner, for atmospheric simulations over Greenland, was illustrated by Bromwich et al. (2001a). Detailed descriptions of the HIRHAM model setup have been given in DKRZ (1992), Roeckner et al. (1996), and Christensen et al. (1996). Some other aspects are described in more detail here, because of their importance to this study.

\section{1) GREEnLAND TOPOGRAPHY AND TOPOGRAPHIC BIASES}

HIRHAM incorporates the GTOPO30 30 arc-second elevation data produced by the U.S. Geological Survey's Earth Resources Observation Systems (EROS) Data Center (Gesch 1994; Gesch and Larson 1996) into the $0.5^{\circ}$ HIRHAM Arctic domain. There are 724 HIRHAM grid cells covering Greenland. When compared to a new, "fully validated" digital elevation model for Greenland (Ekholm 1996; Bamber et al. 2001), GTOPO30 data contain deviations of up to $-840 \mathrm{~m}$ over $0.5^{\circ}$-average HIRHAM grid cells (Fig. 2a). The mean elevation of Greenland (including mountains) in the Ekholm data is $1830 \mathrm{~m}$. The GTOPO30 average is $181 \mathrm{~m}$ smaller. Comparison between individual station elevations measured with differential Global Positioning System (GPS) and $0.5^{\circ} \mathrm{HIRHAM}$ grid cell values also indicate differences exceeding $100 \mathrm{~m}$ in a few cases, even when compared with HIRHAM grid cells based on the Ekholm data (Table 2), underscoring the problem of subgrid-scale comparisons, even over a relatively smooth surface, such as the Greenland ice sheet. Largest biases between the Ekholm data and GPS observations occur, in the steep undulating low-elevation portion of the ice sheet. Ekholm biases in the HIRHAM grid are within $20 \mathrm{~m}$ over the higher parts of the ice sheet, when compared to point GPS measurements. Table 2 compares the uninterpolated 1-km Ekholm elevation data to the GPS AWS elevation data. The last two columns indicate the amount of elevation error introduced by the use of a coarser model resolution. As a result of the complications imposed by elevation errors and the importance of accurately simulating the relatively small area low elevations of the ice sheet, where summertime melting 


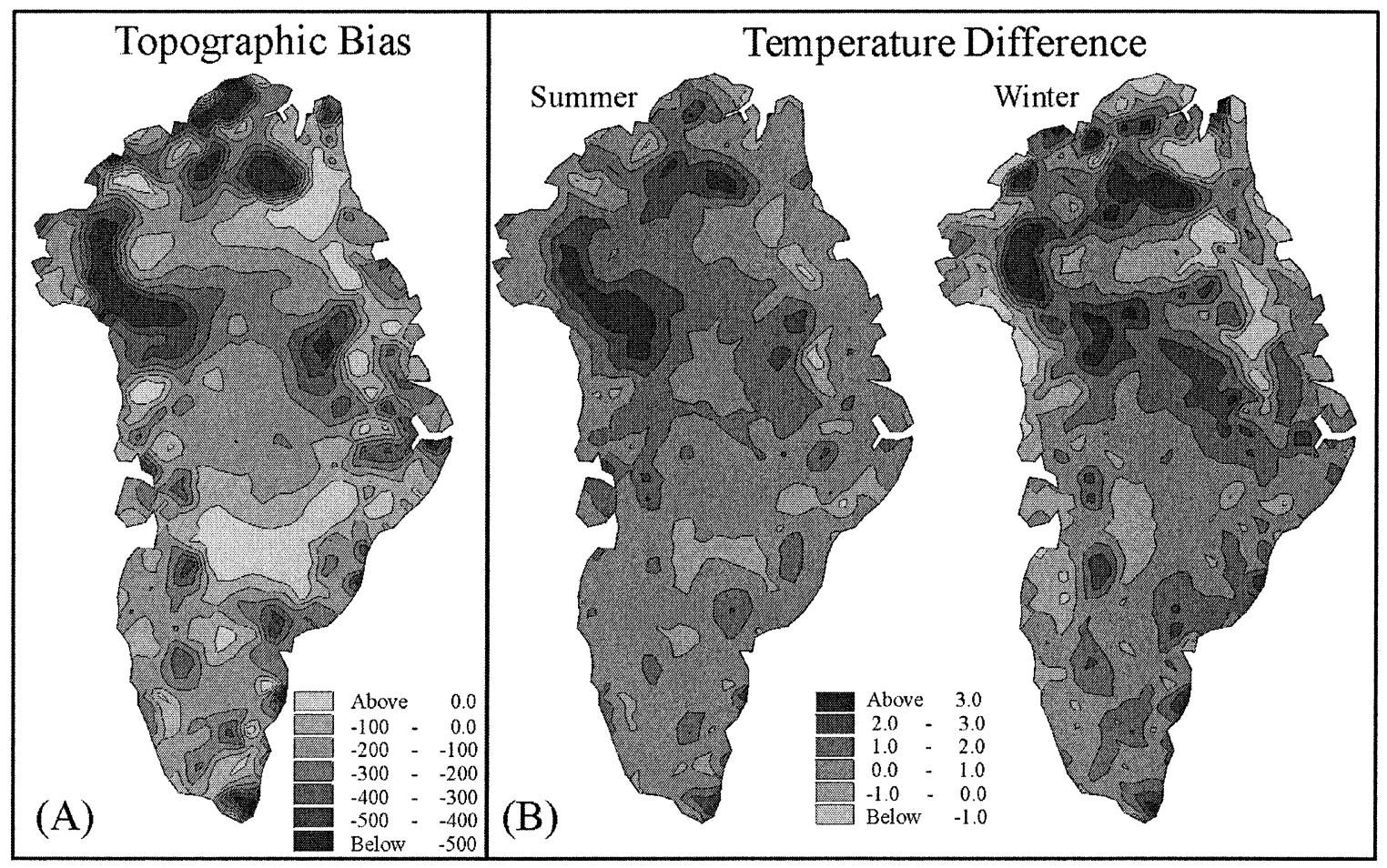

FIG. 2. (a) GTOPO30 elevation bias (GTOPO30 minus Ekholm), and (b) HIRHAM temperature difference due to GTOPO30 bias.

occurs, the present study became somewhat focused on the influence of elevation errors on surface climate parameters.

\section{2) Elevation-BASED MODEl CORRECTIONS}

Model elevation errors introduce significant temperature and pressure biases not due to physical model error. Elevation bias is taken as the difference between model grid elevation, interpolated to the AWS position using the surrounding four grid points, and differential GPS measurements at AWS sites (Table 2). In an effort to reduce biases in the comparison of temperature between the model and observations, the GC-Net observed monthly mean "slope lapse-rate" in temperature is used to adjust model temperature data to the corresponding AWS elevation. The slope lapse-rate is represented by linear regression between GC-Net monthly mean and elevation (e.g., Steffen and Box 2001). Explained variance for this regression on monthly mean data exceeds 95\%. Elevation-based corrections to model temperatures have been made in other studies when model and observation site elevations are significantly different (e.g., Thompson and Pollard 1997; Krinner and Genthon

TABLE 2. GC-Net site elevations and difference with the HIRHAM and Ekholm grids.

\begin{tabular}{|c|c|c|c|c|}
\hline Station & $\begin{array}{c}\text { GPS } \\
\text { elev (m) }\end{array}$ & $\begin{array}{l}\text { Model elevation bias } \\
\text { (50-km HIRHAM grid) } \\
\text { (GTOPO minus GPS) }\end{array}$ & $\begin{array}{l}\text { Model elevation bias } \\
\text { (50-km HIRHAM grid) } \\
\text { (Ekholm minus GPS) }\end{array}$ & $\begin{array}{c}\text { Model elevation bias } \\
(1-\mathrm{km} \text { grid }) \\
\text { (Ekholm DEM minus GPS })\end{array}$ \\
\hline Swiss Camp & 1149 & -157 & -136 & 29 \\
\hline $\mathrm{CP} 1$ & 2022 & -19 & -37 & -26 \\
\hline NASA-U & 2369 & -97 & -17 & -6 \\
\hline GITS & 1887 & -814 & -126 & -34 \\
\hline Humboldt & 1995 & -58 & -18 & -10 \\
\hline Summit & 3208 & -110 & -18 & -6 \\
\hline Tunu-N & 2113 & -2 & 89 & 94 \\
\hline DYE-2 & 2165 & -88 & 41 & 53 \\
\hline JAR1 & 962 & -149 & -173 & 8 \\
\hline Saddle & 2559 & 3 & 15 & 44 \\
\hline South Dome & 2908 & -312 & -103 & 75 \\
\hline NASA-E & 2631 & -319 & -14 & 14 \\
\hline $\mathrm{CP} 2$ & 1990 & 42 & 24 & 29 \\
\hline NGRIP & 2950 & -106 & -22 & 37 \\
\hline NASA-SE & 2425 & -216 & -54 & 65 \\
\hline
\end{tabular}


1999). Here, the lapse-rate in temperature is set to vary monthly, for example, $5.0^{\circ} \mathrm{C} \mathrm{km}^{-1}$ June-July, peaking at $9.4^{\circ} \mathrm{C} \mathrm{km}^{-1}$ in November after Steffen and Box (2001). The correction to model surface pressure is made using the hypsometric equation as in Cassano et al. (2001). The vertical temperature structure for the pressure correction is estimated using HIRHAM temperature data.

\section{3) Surface Albedo}

HIRHAM albedo is in two shortwave wavelength intervals $(0.25-0.68$ and $0.68-4.0 \mu \mathrm{m})$. Over snow-free land areas, annual-mean background albedo $\left(A_{\mathrm{sb}}\right)$ is specified from satellite data (Hagemann et al. 1999). In snow covered areas the surface albedo $\left(A_{\text {surf }}\right)$ is modified according to $A_{\text {surf }}=A_{\mathrm{sb}}+\left(A_{s}-A_{\mathrm{sb}}\right)\left[S_{n} /\left(S_{n}+S_{n, \text { crit }}\right)\right]$, where $A_{s}$ is the snow albedo, $S_{n}$ is the simulated snow depth (in water equivalents), and $S_{n, \text { crit }}=0.01 \mathrm{~m}$ is a critical snow depth. For $S_{n} \gg S_{n \text {,crit }}$, the surface albedo approaches the albedo of snow. The albedo of snow and ice surfaces $\left(A_{s}\right)$ itself is a function of surface type, surface temperature $\left(T_{s}\right)$, and fractional forest area. For land ice surfaces, the following holds according to Robock (1980): For a melting surface $\left(T_{s}=0^{\circ} \mathrm{C}\right)$, the albedo remains fixed at a value of $60 \%$. For a cold surface $\left(T_{s}<-10^{\circ} \mathrm{C}\right)$, the albedo is fixed to a value of $80 \%$. Otherwise, the albedo is a prescribed function of $T_{s}: A_{s}=0.6-0.02 T_{s} ; T_{s}$ in ${ }^{\circ} \mathrm{C}$.

\section{4) PBL AND SURFACE FLUXES}

Model atmospheric PBL parameterizations provide the physical link between the atmosphere and the surface for exchanges of heat, moisture, and momentum. These are modulated by surface buoyant stability. Thus, accurate descriptions of the vertical energy and momentum exchanges and temperature structure are crucial (Dethloff et al. 2001). In HIRHAM, the turbulent fluxes at the surface are calculated from the Monin-Obukhov similarity theory with second-order, turbulent kinetic energy closure (Brinkop and Roeckner 1995). The same approach is used to diagnose near-surface variables (2$\mathrm{m}$ temperature, $10-\mathrm{m}$ wind). The turbulent fluxes at the surface are calculated according to the bulk transfer relation. The transfer coefficients differ for momentum and heat/water vapor and depend among other things on the surface roughness length $z_{0}$. Over land, $z_{0}$ is specified as a function of the subgrid-scale orography and vegetation. Not only the surface elements, but also small-scale orographic features affect the turbulent exchange. To take the effect of these eddies on the turbulent exchange into account, an effective roughness length is introduced that is derived from the variance of the scale-scale orography. So, $z_{0}$ is the sum of the surface value for snow $(1 \mathrm{~mm})$ and the effective $z_{0}$. Van Lipzig et al. (1999) showed that there are unrealistic large values of $z_{0}$ at the steep edges of ice sheets.

\section{5) Model UnCERTAinTY}

RCMs constitute complex dynamical systems characterized by substantial nonlinearity. Therefore, a single simulation represents only one realization of the atmospheric conditions and has an implicit uncertainty based on model noise alone originating from internal nonlinear processes (e.g., Noguer et al. 1998; Giorgi and Bi 2000; de Elía et al. 2002). This simulation uncertainty is caused by uncertainties in initial and boundary conditions, model parameterizations, and numerical sensitivity. Recent work has focused on gauging this uncertainty in HIRHAM. On the basis of January and July ensemble runs, Rinke and Dethloff (2000) estimated up to $4 \mathrm{hPa}$ for the monthly averaged mean sea level pressure noise due to uncertainty in initial conditions. This internal noise for monthly mean $2 \mathrm{~m}$ air temperatures is up to $3 \mathrm{~K}$, and $30 \mathrm{~W} \mathrm{~m}^{-2}$ for the net shortwave radiation. The model sensitivity concerning the physical parameterizations has been estimated on the basis of many simulations and sensitivity experiments (Rinke et al. 1997, 2000; Rinke and Dethloff 2000; Dethloff et al. 2001). This sensitivity is of about the same order of magnitude as the internal model noise. Therefore, there are really rather loose bounds for this comparison to be taken into account when conclusions about biases are made.

\section{Methods}

The 1998 annual cycle and the summer melt period, May through August, 1991-98, are considered. Comparisons are made between monthly averages from the HIRHAM model and GC-Net in situ observations on the Greenland ice sheet. HIRHAM monthly means are calculated from 6-h output. GC-Net monthly means are based on hourly observations. For the interannual comparison, only quantities with at least an 8-yr-long data record have been used. Percent biases shown in this study are calculated as model minus observations divided by the observations, thus removing the effect of seasonally varying magnitudes. The standard deviation is calculated from interannual comparisons to help quantify the model skill in simulating interannual variability in multiyear simulations. HIRHAM variance is gauged as the standard deviation of 6-h samples from the monthly average. GC-Net variance is gauged similarly, with the hourly data. Comparisons between model grid points and station points are made by linear interpolation of the model data to the station position using the four surrounding model grid points. In the case of two observational sites located near the coast, (JAR1 and Swiss Camp), one of four surrounding grid points is over land. During summer, the land point has, for example, a much lower surface albedo. This problem illustrates the difficulty in simulating the narrow (and steep) ablation zone of the Greenland ice sheet with a fixed horizontal model domain. 
Sensitivity simulations with the accurate Ekholm data were made to solidify conclusions about the effect of inaccurate GTOPO30 Greenland elevation data in HIRHAM. Results are shown as the difference in a given climate parameter with old and new elevation data.

\section{Results and discussion}

\section{a. Two-meter temperature}

Before the elevation-based correction, temperature biases were strongly positive-2-5 K. After the lapse-rate correction, the monthly average annual cycle in 2-m air temperature corresponds well with observations (Fig. $3)$. The extremely low winter temperatures in central Greenland and the decrease of the annual-cycle amplitude from the central to the near-coastal sites is well reproduced. Temperature biases seem to depend on the station's elevation. The seasonal cycle of temperature is therefore shown for high-elevation sites (NGRIP, Summit, Saddle, South Dome), nine intermediate-elevation sites, and low-elevation sites (JAR1, Swiss Camp) (Fig. $3)$. The model reproduces high-elevation site temperature observations for all months within the measurement variance and model uncertainties. Seven-twelfths of ensemble monthly biases are lower than $1 \mathrm{~K}$. Nevertheless, there is up to $3.6 \mathrm{~K}$ monthly warm bias at intermediate sites, particularly in the transition into and out of winter, that is, November and February. Opposite, however, to the general warm bias at intermediate-elevation sites is a pronounced winter cool bias $(-5$ to $-2 \mathrm{~K})$ at lowelevation sites. Comparison statistics are given in Table 3 . The temperature biases are also thought to result partly from deficiencies in the simulation of the boundary layer, that is, surface fluxes and temperature profile. This hypothesis is supported by Dethloff et al. (2001). Still, there is the need to further adapt the model specifically to the extreme polar conditions. The PBL is often too shallow for the present vertical-model layering to resolve. Based on HIRHAM simulations over Antarctica, van Lipzig et al. (1999) showed the strong influence of the boundary layer resolution on the accuracy of nearsurface temperature.

Year-to-year variability in HIRHAM closely resembles the observations at Swiss Camp and Summit (Fig. 4), although with smaller amplitude, as indicated by the magnitude of the multiyear standard deviations in Table 4. At Summit, representative of high-elevation sites, the results are within the observational and model uncertainties. At Swiss Camp, representative of low-elevation sites, the model indicates the warm bias detected in summer 1998 is consistent over all 8 yr. At both sites, the correlation is worst in July. The smaller-amplitude interannual variability could be linked with the fact that the model undersamples relative to the AWS observations, that is, monthly means based on 6-hourly output as opposed to hourly output in the case of the AWS observations.
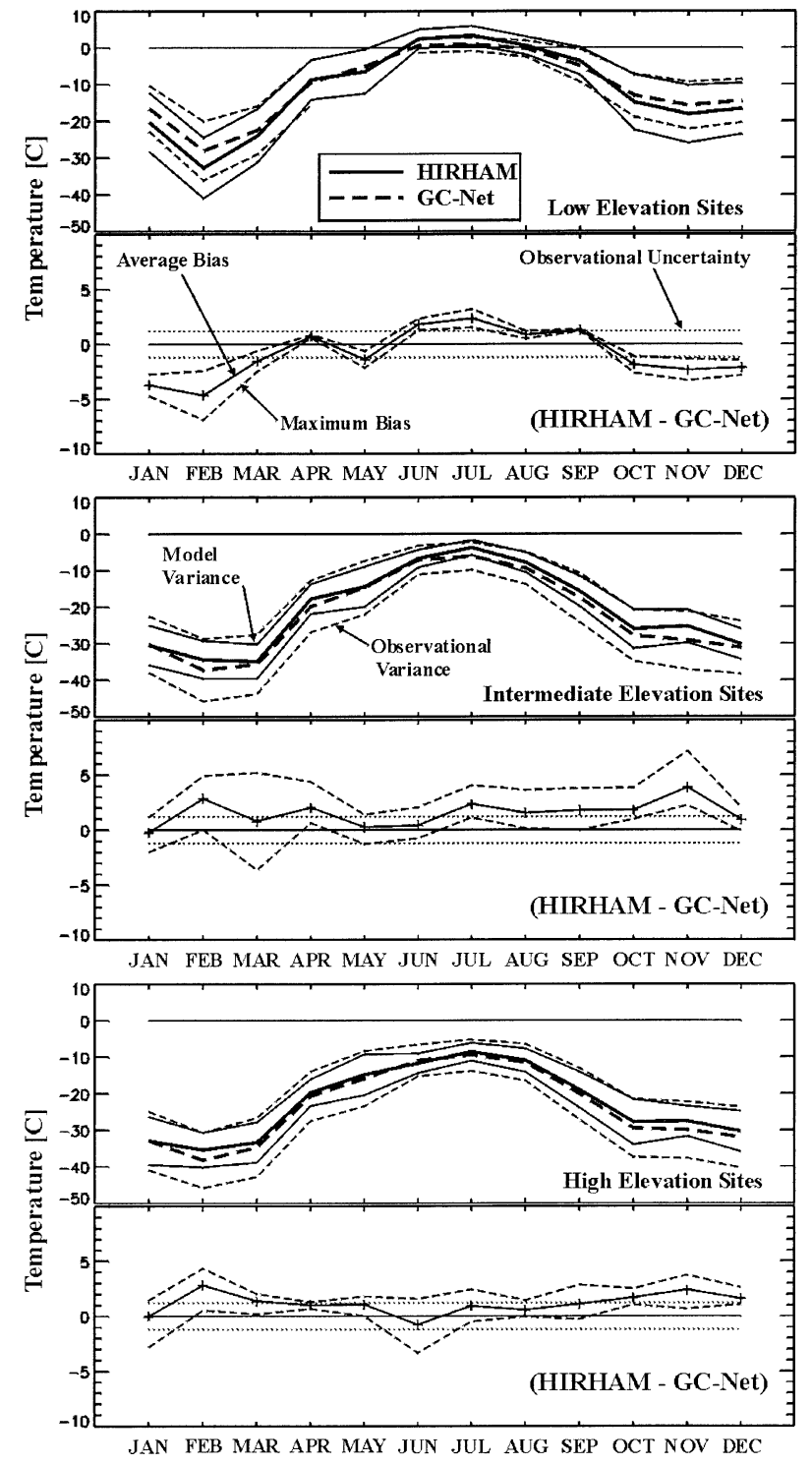

FIG. 3. Comparison of 1998 monthly HIRHAM 2-m air temperature with GC-Net observations for different elevation zones.

\section{b. Surface pressure}

A HIRHAM positive pressure bias is consistently observed at AWS sites (Fig. 5), due to the rather consistent negative elevation bias. The hydrostatic correction greatly reduces the bias, yet does not altogether eliminate the bias since the large positive monthly biases of $15 \mathrm{hPa}$ at only two stations (South Dome, NASA-E) have a large elevation bias of $300 \mathrm{~m}$. Thus, the hydrostatic correction may be inadequate, bringing into question the vertical temperature structure of the layer over which the correction is made. An uncertainty in the stations' elevation of $20 \mathrm{~m}$ introduces an uncertainty of $2 \mathrm{hPa}$. An uncertainty of the temperature of $10 \mathrm{~K}$ introduces an uncertainty of $1 \mathrm{hPa}$. Looking at individual stations where little model elevation bias exists, there 
TABLE 3. Comparison of HIRHAM and GC-Net for a monthly mean annual cycle in 1998 (12 months).

\begin{tabular}{|c|c|c|c|c|c|c|}
\hline Parameter & Station & $\begin{array}{l}\text { HIRHAM } \\
\text { value }\end{array}$ & $\begin{array}{l}\text { HIRHAM } \\
\text { bias }\end{array}$ & $\%$ bias & Rmse & $r$ \\
\hline \multicolumn{7}{|l|}{ Temperature (k) } \\
\hline & Swiss Camp & 261 & -1 & 0.2 & 2 & 0.99 \\
\hline & DYE-2 & 257 & 2 & 0.7 & 2 & 0.99 \\
\hline & JAR1 & 262 & -1 & 0.5 & 3 & 0.99 \\
\hline & Saddle & 255 & 2 & 0.8 & 2 & 0.99 \\
\hline & South Dome & 255 & 1 & 0.6 & 2 & 0.99 \\
\hline & NGRIP & 245 & 1 & 0.3 & 2 & 0.99 \\
\hline \multicolumn{7}{|l|}{ Pressure (hPa) } \\
\hline & NASA-U & 751 & 4 & 0.5 & 5 & 0.96 \\
\hline & Humboldt & 790 & 8 & 1.0 & 8 & 0.99 \\
\hline & Summit & 662 & -6 & 0.9 & 6 & 0.99 \\
\hline & Tunu-N & 778 & -2 & 0.3 & 3 & 0.99 \\
\hline & DYE-2 & 768 & -1 & 0.1 & 1 & 0.99 \\
\hline & JAR1 & 905 & 8 & 0.9 & 8 & 0.99 \\
\hline & NASA-E & 733 & 11 & 1.5 & 11 & 0.99 \\
\hline & $\mathrm{CP} 2$ & 789 & -2 & 0.3 & 2 & 0.99 \\
\hline & NGRIP & 696 & 4 & 0.6 & 4 & 0.99 \\
\hline \multicolumn{7}{|l|}{ Wind speed $\left(\mathrm{m} \mathrm{s}^{-1}\right)$} \\
\hline & NASA-U & 15 & 7 & 95 & 8 & 0.92 \\
\hline & Humboldt & 14 & 7 & 92 & 7 & 0.63 \\
\hline & Tunu-N & 12 & 5 & 76 & 6 & 0.72 \\
\hline & DYE-2 & 11 & 4 & 60 & 6 & 0.94 \\
\hline & JAR1 & 11 & 2 & 22 & 3 & 0.82 \\
\hline & $\mathrm{CP} 2$ & 15 & 7 & 88 & 8 & 0.86 \\
\hline \multicolumn{7}{|c|}{ Wind direction (true degrees) } \\
\hline & Swiss Camp & 140 & 10 & - & 12 & 0.37 \\
\hline & NASA-U & 164 & 29 & - & 30 & 0.44 \\
\hline & Humboldt & 172 & -1 & - & 6 & 0.58 \\
\hline & Tunu-N & 291 & 29 & - & 30 & 0.61 \\
\hline & JAR1 & 141 & 11 & - & 13 & 0.27 \\
\hline & NASA-E & 301 & 41 & - & 92 & 0.50 \\
\hline & $\mathrm{CP} 2$ & 134 & -4 & - & 16 & -0.03 \\
\hline & NGRIP & 201 & 22 & - & 28 & 0.55 \\
\hline \multicolumn{7}{|c|}{ Incoming SW (W m-2) } \\
\hline & NASA-U & 123 & -15 & 11 & 25 & 0.99 \\
\hline & DYE-2 & 113 & -30 & 21 & 44 & 0.98 \\
\hline & JAR1 & 111 & -9 & 8 & 15 & 0.99 \\
\hline & Saddle & 121 & 1 & 1 & 16 & 0.99 \\
\hline & South Dome & 125 & -5 & 4 & 18 & 0.99 \\
\hline & CP2 & 109 & -24 & 18 & 35 & 0.99 \\
\hline \multicolumn{7}{|c|}{ Reflected SW (W m ${ }^{-2}$ ) } \\
\hline & NASA-U & 97 & -15 & 14 & 24 & 0.99 \\
\hline & Humboldt & 79 & -26 & 25 & 41 & 0.99 \\
\hline & Tunu-N & 88 & -22 & 20 & 36 & 0.99 \\
\hline & DYE-2 & 82 & -39 & 33 & 55 & 0.97 \\
\hline & JAR1 & 81 & -13 & 14 & 21 & 0.99 \\
\hline & Saddle & 92 & -7 & 7 & 15 & 0.99 \\
\hline & South Dome & 95 & -16 & 14 & 25 & 0.99 \\
\hline & NASA-E & 92 & -16 & 15 & 32 & 0.99 \\
\hline & $\mathrm{CP} 2$ & 81 & -26 & 24 & 38 & 0.98 \\
\hline & NGRIP & 96 & -10 & 9 & 18 & 0.99 \\
\hline \multicolumn{7}{|l|}{ Albedo (\%) } \\
\hline & Swiss Camp & 67 & -11 & 15 & 12 & 0.97 \\
\hline & CP1 & 75 & -10 & 11 & 11 & 0.62 \\
\hline & NASA-U & 78 & -3 & 4 & 5 & 0.12 \\
\hline & Humboldt & 75 & -11 & 12 & 12 & 0.80 \\
\hline & Summit & 80 & -7 & 8 & 7 & 0.29 \\
\hline & Tunu-N & 77 & -10 & 12 & 11 & 0.58 \\
\hline & DYE-2 & 75 & -9 & 11 & 11 & 0.31 \\
\hline & JAR1 & 65 & -13 & 17 & 16 & 0.62 \\
\hline & Saddle & 76 & -4 & 6 & 6 & 0.55 \\
\hline & South Dome & 77 & -8 & 9 & 10 & 0.01 \\
\hline & NASA-E & 76 & -13 & 15 & 14 & 0.22 \\
\hline & $\mathrm{CP} 2$ & 77 & -1 & 1 & 11 & -0.06 \\
\hline & NGRIP & 80 & 4 & 5 & 8 & -0.36 \\
\hline & NASA-SE & 74 & -13 & 15 & 13 & 0.83 \\
\hline
\end{tabular}




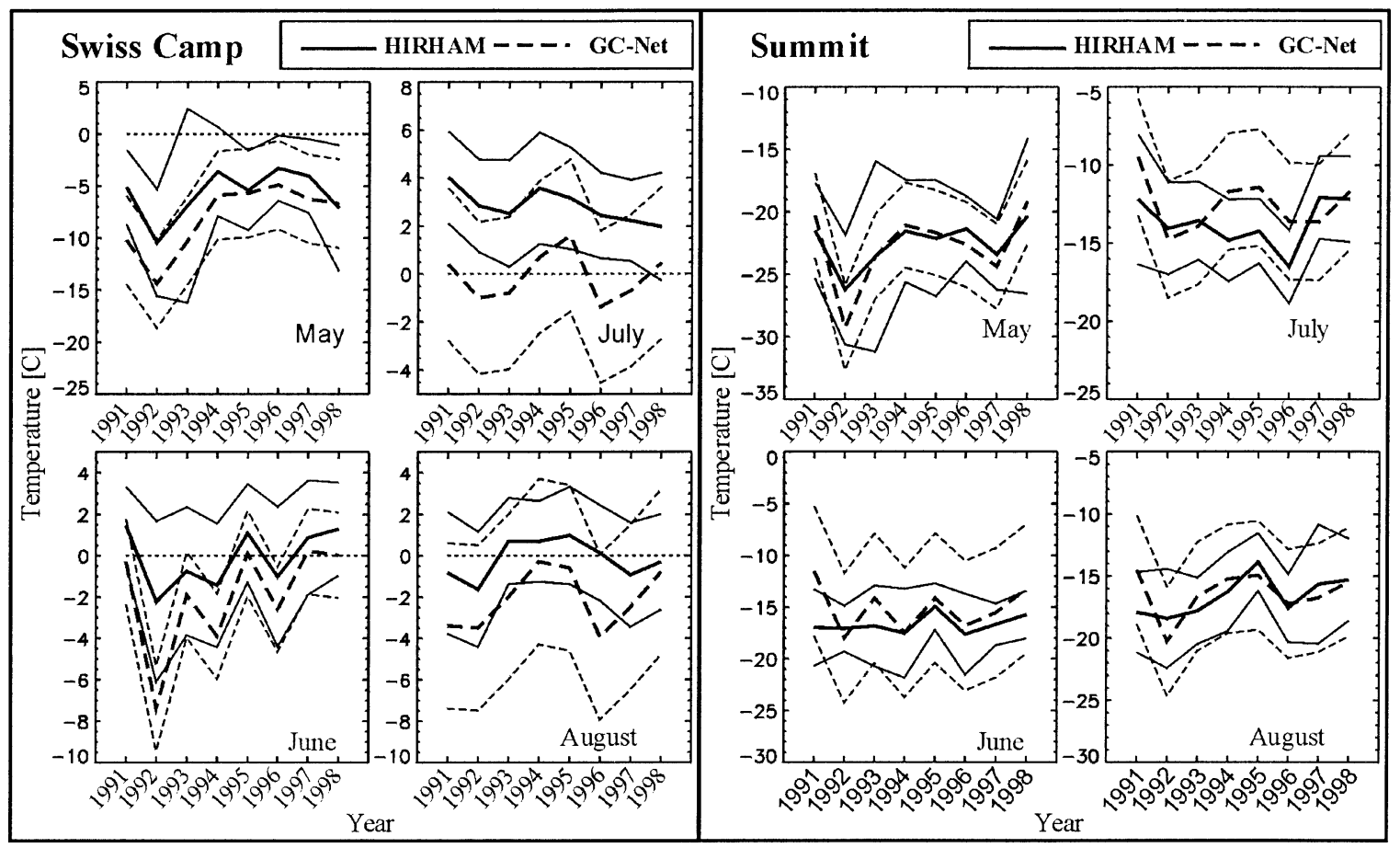

FIG. 4. Comparison of interannual temperature variations between HIRHAM and GC-Net observations for Swiss Camp and Summit (May-Aug, 1991-98). The central lines are bounded by one standard deviation lines.

TABLE 4. Interannual comparison for available data at Swiss Camp and Summit, 1991-98.

\begin{tabular}{|c|c|c|c|c|c|c|c|c|c|}
\hline Site & Parameter & Month & HIRHAM & $\begin{array}{l}\text { HIRHAM } \\
\text { bias }\end{array}$ & $\%$ bias & $\begin{array}{l}\text { HIRHAM } \\
\text { std }\end{array}$ & $\begin{array}{l}\text { GC-Net } \\
\text { std }\end{array}$ & $r$ & $N$ \\
\hline \multirow[t]{5}{*}{ Swiss Camp } & Temperature $(\mathrm{K})$ & & & & & & & & \\
\hline & & May & 267.4 & 2.3 & 0.9 & 2.4 & 3.3 & 0.83 & 8 \\
\hline & & Jun & 273.1 & 1.9 & 0.7 & 1.4 & 2.7 & 0.93 & 8 \\
\hline & & Jul & 270.4 & 2.9 & 1.1 & 0.7 & 1.0 & 0.47 & 8 \\
\hline & & Aug & 273.0 & 2 & 0.7 & 0.9 & 1.4 & 0.63 & 8 \\
\hline \multirow[t]{5}{*}{ Summit } & Temperature $(\mathrm{K})$ & & & & & & & & \\
\hline & & May & 250.7 & 0.2 & 0.1 & 1.9 & 3.1 & 0.96 & 8 \\
\hline & & Jun & 256.5 & -1.6 & 0.6 & 0.9 & 2.2 & 0.49 & 8 \\
\hline & & Jul & 259.5 & -1.2 & 0.5 & 1.5 & 1.7 & 0.33 & 8 \\
\hline & & Aug & 256.6 & -0.2 & 0.1 & 1.5 & 1.8 & 0.53 & 8 \\
\hline \multirow{20}{*}{ Swiss Camp } & Wind speed & & & & & & & & \\
\hline & $\left(\mathrm{m} \mathrm{s}^{-1}\right)$ & May & 11.5 & 4.5 & 64.7 & 1.5 & 0.8 & 0.11 & 8 \\
\hline & & Jun & 10.3 & 3.2 & 51.7 & 1.7 & 1.1 & 0.37 & 8 \\
\hline & & Jul & 11.2 & 5.2 & 86.3 & 2.6 & 0.9 & -0.36 & 8 \\
\hline & & Aug & 9.7 & 3.2 & 50.0 & 1.9 & 0.7 & -0.09 & 8 \\
\hline & Incoming SW & & & & & & & & \\
\hline & $\left(\mathrm{W} \mathrm{m}^{-2}\right)$ & May & 237.6 & -40.8 & 14.7 & 24.5 & 30.5 & 0.90 & 6 \\
\hline & & Jun & 255.9 & -59.0 & 18.7 & 34.6 & 5.1 & 0.05 & 6 \\
\hline & & Jul & 268.4 & -9.1 & 3.3 & 23.5 & 16.5 & 0.12 & 6 \\
\hline & & Aug & 141.2 & -39.4 & 21.8 & 20.4 & 18.6 & 0.83 & 6 \\
\hline & Reflected SW & & & & & & & & \\
\hline & $\left(\mathrm{W} \mathrm{m}^{-2}\right)$ & May & 154.5 & -76.1 & 33.0 & 22.3 & 16.6 & 0.75 & 6 \\
\hline & & Jun & 146.1 & -100.8 & 40.8 & 19.1 & 17.2 & -0.60 & 6 \\
\hline & & Jul & 149.4 & -50.6 & 25.3 & 13.2 & 27.2 & -0.04 & 6 \\
\hline & & Aug & 80.4 & -58.8 & 42.2 & 11.8 & 21.8 & 0.89 & 6 \\
\hline & Albedo (\%) & & & & & & & & \\
\hline & & May & 64.9 & -16.6 & 20.4 & 3.8 & 4.5 & -0.36 & 6 \\
\hline & & Jun & 57.1 & -19.2 & 25.2 & 1.1 & 7.0 & 0.70 & 6 \\
\hline & & Jul & 55.7 & -13.6 & 19.6 & 0.2 & 9.7 & -0.17 & 6 \\
\hline & & Aug & 56.9 & -16.7 & 22.7 & 0.6 & 6.7 & -0.06 & 6 \\
\hline
\end{tabular}




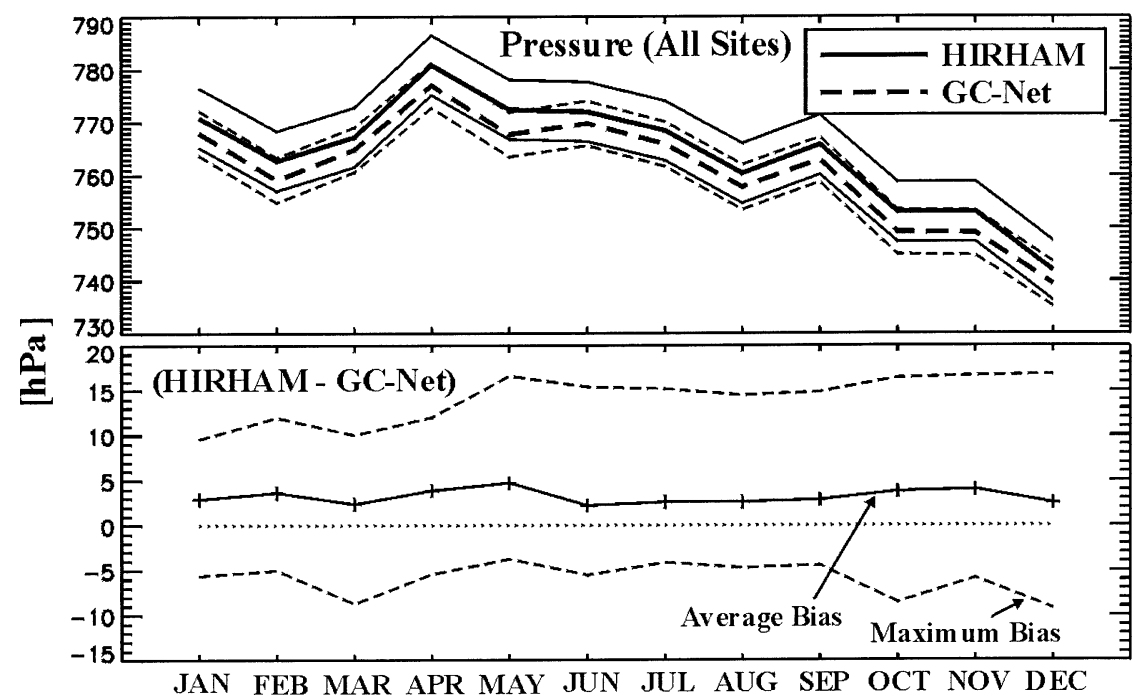

FIG. 5. Comparison of the 1998 seasonal cycle HIRHAM surface pressure with GC-Net observations (averaged over all sites). The central lines are bounded by one standard deviation lines.

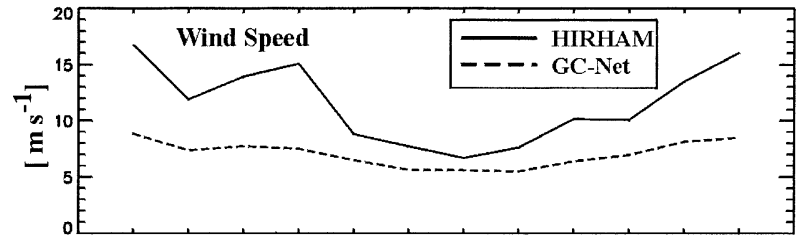

JAN FEB MAR APR MAY JUN JUL AUG SEP OCT NOV DEC

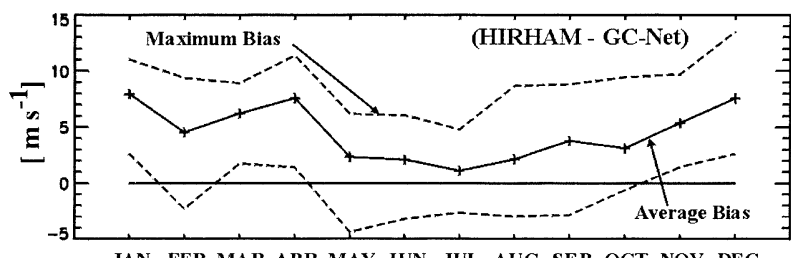

JAN FEB MAR APR MAY JUN JUL AUG SEP OCT NOV DEC

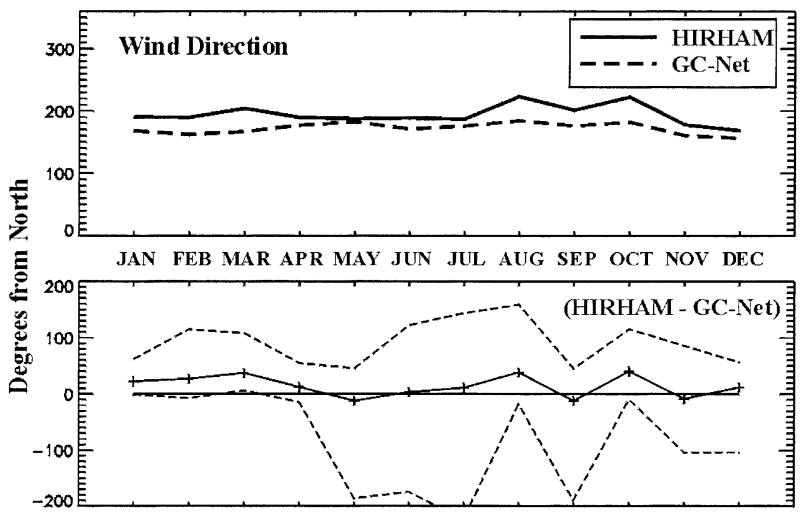

JAN FEB MAR APR MAY JUN JUL AUG SEP OCT NOV DEC

FIG. 6. Comparison of the 1998 seasonal cycle HIRHAM 10-m wind speed and direction with GC-Net observations (averaged over all sites). is often a small negative pressure bias. This would indicate a slightly too intense cyclonic activity, that is, either the number of cyclones are larger or individual cyclones are deeper, as found in many other RCMs (e.g., Jones et al. 1995). Other reasons for the pressure offsets are unclear. Besides the model pressure biases (see comparison statistics in Table 3 and Fig. 5), there is a good representation of month-to-month variability.

\section{c. Ten-meter wind speed and direction}

In comparison with the observations, model 10-m wind speeds are on average $20 \%$ to $100 \%$ too high, annually and interannually (Tables 3 and 4). During winter, this bias is greatest, with some $150 \%$ wind speed biases, at low-elevation sites. As with the observations, the model simulates an annual cycle in wind speed with maximum values in winter and minimum values in summer (Fig. 6). The capturing of the annual cycle in wind speed leads to high annual-cycle correlation values (Table 3). Yet, these high correlation values are spurious given that the correlation of interannual values is very low (Table 4).

It appears that the surface friction effects are not adequately accounted for in the model, despite the fact that modeled surface roughness lengths are on the order of those used in observation-based wind profile and turbulent heat flux calculations, that is, $10^{-4} \mathrm{~m}$. There is a basic problem arising from the difficulty of accurately interpolating the lowest model-level winds from a height of 30 to $10 \mathrm{~m}$ under statically stable conditions. In these conditions, wind speed and direction can change markedly over a height of $20 \mathrm{~m}$. The only adequate solution to this problem is to use a finer vertical resolution near 
the surface to attempt to resolve the details of the nearsurface wind profile.

Positive biases of $10^{\circ}$ to $30^{\circ}$ in wind direction are evident from the comparison (Fig. 6). For example, modeled wind directions are more southerly for west Greenland sites. This could contribute further to the model warm bias, through warm air advection. As, the model wind speeds are significantly greater than in the observations, the cause of the wind direction bias is thought to be the result of too-large Coriolis turning in the model. The Coriolis effect is proportional to wind speed and latitude. Largest deviations are found in north and east Greenland. The predominantly easterly wind direction at South Dome does not occur in the model. The near-surface winds are influenced by the local (subgrid) topography. Furthermore, the position of the lowest model levels is somewhat limited for examination of surface air meteorological parameters. This excessive cross-slope turning reflects an overly weak turbulent drag in the model force balance for winds, possibly due to the coarse vertical resolution near the surface. The HIRHAM $10-\mathrm{m}$ wind directions are probably more indicative of the 30-m level than of a katabatic layer. Wind directions aloft would be turned more parallel to the cross-slope direction than at $10 \mathrm{~m}$ for katabatic flow. The lacking turbulent drag in the model could also be due to problems with the model PBL parameterizations.

\section{d. Solar radiation fluxes and surface albedo}

Figure 7 shows the 1998 seasonal cycles of incoming and reflected solar radiation and surface albedo. In comparison with the observations, there is a consistent negative bias in modeled incoming shortwave radiation flux both for the annual cycle and interannually (Tables 3 and 4). Interannual variability is overestimated by the model in 3 of 4 months, but not by a large margin. Monthly mean negative biases at individual stations are between $16 \%$ and $44 \%$ for the 1998 annual cycle and between $20 \%$ and $80 \%$ interannually. In summer, this corresponds to a monthly mean underestimate of 60 to $80 \mathrm{~W} \mathrm{~m}^{-2}$. A negative bias in incoming shortwave radiation is maintained by the model for four-fifths of the sites compared in all 4 summer months. Apparently, there are biases in either the clear-sky fluxes, clouds, and/or cloud-radiation interactions. The rates of these processes on the bias cannot be clarified here without detailed cloud measurements.

HIRHAM albedos are consistently lower than GCNet values for the annual cycle and interannually. On the annual average, the albedo is underestimated by between 0.01 and 0.13 . Rmse errors of monthly data are between 0.05 and 0.14 . Largest albedo biases are found at intermediate-elevation sites due to a positive temperature bias caused in part by the negative elevation bias and the weaker than expected temperature inversions. Model interannual variability in albedo is smaller in the observations (Table 4). The negative bias in al-
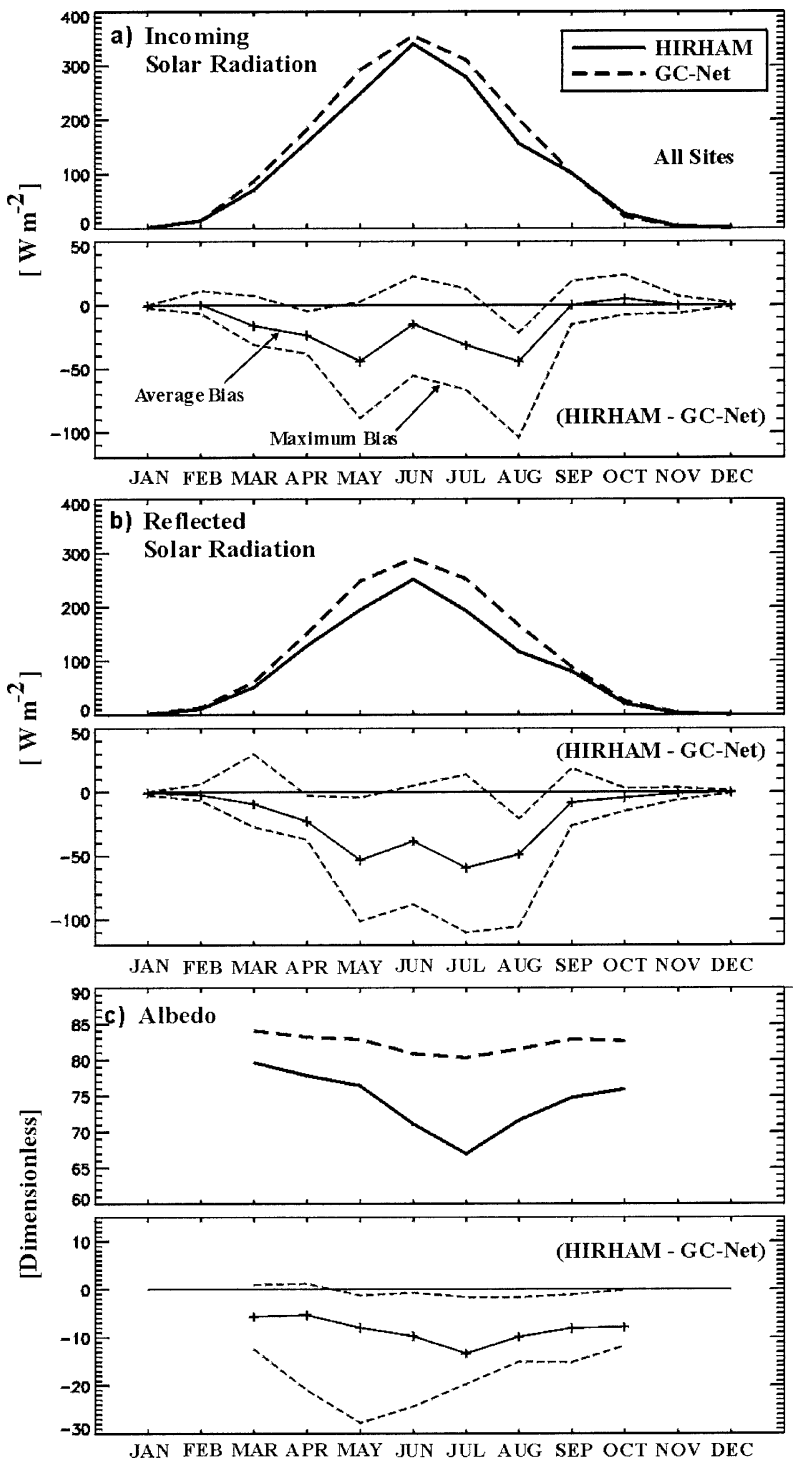

FIG. 7. Comparison of the 1998 seasonal cycle HIRHAM radiation fluxes with GC-Net observations (a) incoming shortwave, (b) reflected shortwave, (c) albedo (averaged over all sites).

bedo is maintained for all years, except extreme melt years, such as 1995 at Swiss Camp. The negative bias in modeled surface albedo may contribute to the negative bias in incoming solar radiation since multiple scattering is taken into account by the model. It seems that the albedo parameterization does not correspond well with the albedo over Greenland. The parameterization gives too low albedo values for surface temperatures near the freezing point as also found by van $\mathrm{Li}_{-}$ pzig et al. (1999). The reflected solar radiation in the model is too low for at least two reasons: too-low surface albedo and negatively biased incoming solar radiation. 

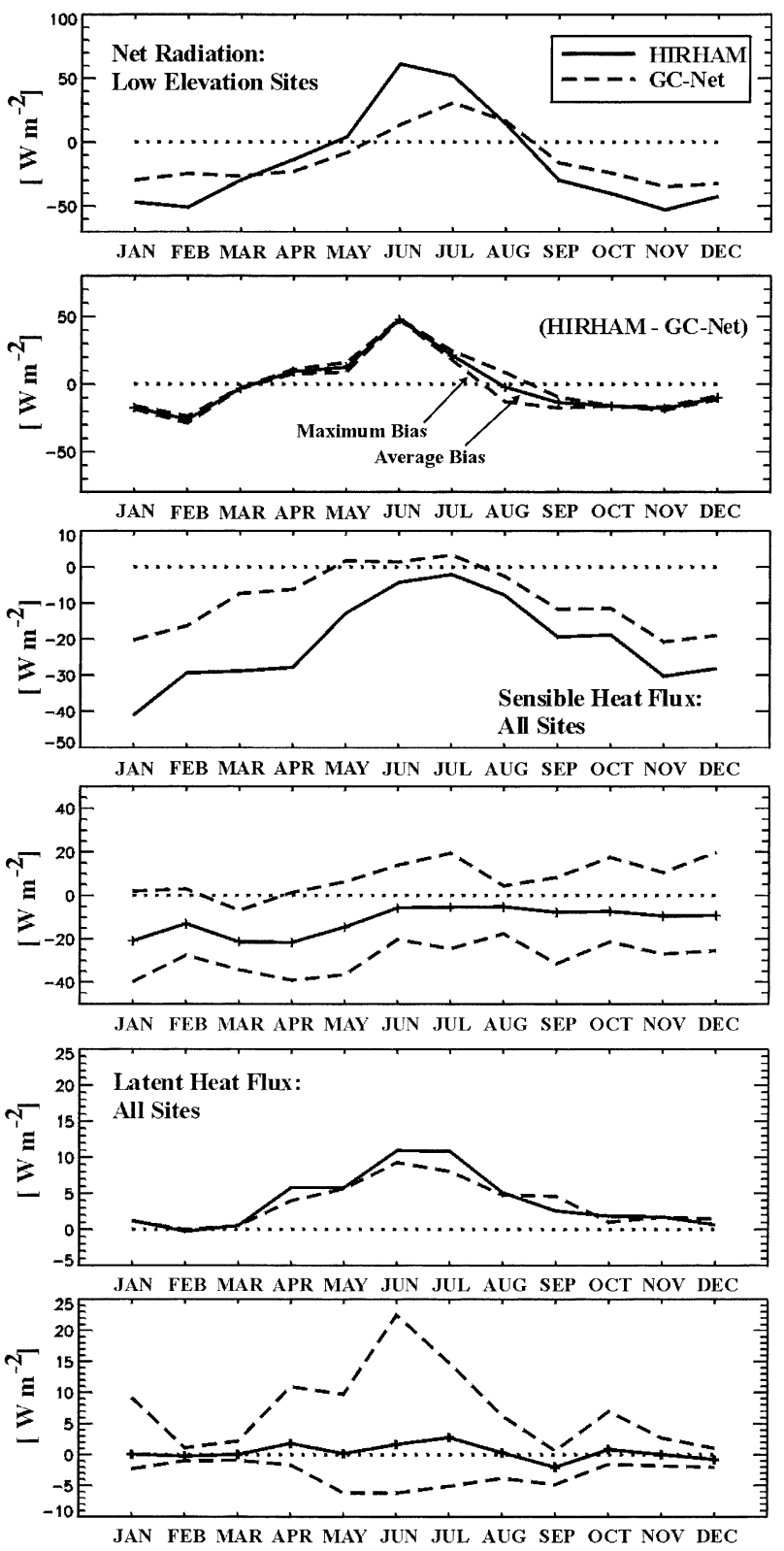

FIG. 8. (top) Comparison of the 1998 seasonal cycle HIRHAM net radiation (averaged over Swiss Camp and JAR1) and the difference with GC-Net, (middle) same as (top) but for sensible heat flux, (bottom) same as (top) but for latent heat flux.

\section{e. Net radiation}

At the present stage of quality control and observational data correction, net radiometer accuracy is thought to be sufficient only at low-elevation sites. Therefore, the comparison considers Swiss Camp and JAR1 data only. At these two sites, modeled net radiation is too low in winter and too great in summer (Fig. 8 , Table 5). The negative bias in incoming shortwave radiation and albedo leads to the positive bias in the net radiation in summer months. The summer positive bias would be even greater if the incoming shortwave ra- diation were not also negatively biased. The summer bias at Swiss Camp and JAR1 is also strongly influenced by the low albedo present over the adjacent land grid value used in interpolation to these station coordinates. We did not attempt to remove this particular bias given complications to interpolate to the station location and to illustrate the problem in resolving the narrow ablation zone, even with a relatively high-resolution regional climate model. Summertime modeled net longwave radiation corresponds fairly well with the measurements $\left(-5 \mathrm{~W} \mathrm{~m}^{-2}\right.$ averaged bias), not shown. In winter, modeled net longwave radiation is up to $25 \mathrm{~W} \mathrm{~m}^{-2}$ more negative than observed. The negative winter bias is thought to be the result of too warm surface temperature and the apparent underestimation of cloud amount.

\section{f. Sensible and latent heat fluxes}

Sensible heat fluxes $\left(Q_{H}\right)$ calculated from GC-Net data and output from HIRHAM both indicate that the atmosphere loses heat to the surface throughout the year, particularly in winter (Fig. 8). Surface heating from the atmosphere is due to the vertical temperature gradient directed toward the surface by the temperature inversion. In summer, however, GC-Net calculations indicate that the atmosphere may gain a small amount of heat from the surface. HIRHAM $Q_{H}$ does not indicate this summer surface heating by the atmosphere. Unstable conditions over snow in summer have been observed in other experiments (e.g., Cullen and Steffen 2001), apparently due to the slow response of snowpack temperature to sensible heating. HIRHAM treatment of the ice sheet surface includes too great snowpack thermal diffusivity (van Lipzig et al. 1999). HIRHAM $Q_{H}$ is overestimated, by $20 \mathrm{~W} \mathrm{~m}^{-2}$ in winter and about $5 \mathrm{~W}$ $\mathrm{m}^{-2}$ in summer (Fig. 8, Table 5). Larger than observed $Q_{H}$ would also result from warmer than observed nearsurface air temperatures and too great wind speeds. However, this is not clear, given that the HIRHAM inversion strength is probably not as large as in reality (Dethloff et al. 2002).

The annual cycle of HIRHAM and GC-Net bulk latent heat flux $\left(Q_{E}\right)$ are equivalent (Fig. 8), indicating the tendency for water vapor mass loss from the surface in summer and near-zero flux in winter or even some water vapor deposition. Differences between HIRHAM and GC-Net values are $<5 \mathrm{~W} \mathrm{~m}^{-2}$ in all monthly average cases. This bias is, however, not insignificant because monthly average $Q_{E}$ values are less than $20 \mathrm{~W} \mathrm{~m}^{-2}$. It should also be noted that more accurate methods, that is, nonbulk methods, applied to GC-Net data indicate larger negative $Q_{E}$ in winter (Box and Steffen 2001). Bulk methods, which assume surface saturation with respect to water vapor, yield negative $Q_{E}$ only in cases of extreme temperature inversion. Negative bulk $Q_{E}$ values tend to be too small (Box and Steffen 2001), particularly at high-elevation sites. It has been noted in earlier studies that deposition is underestimated in the 
TABLE 5. Comparison of energy balance quantities in HIRHAM and from the GC-Net data for a monthly mean annual cycle in 1998 (12 months).

\begin{tabular}{|c|c|c|c|c|c|c|}
\hline Parameter & Site & $\begin{array}{l}\text { HIRHAM } \\
\text { value }\end{array}$ & $\begin{array}{l}\text { HIRHAM } \\
\text { bias }\end{array}$ & $\%$ bias & Rmse & $r$ \\
\hline Net radiation $\left(\mathrm{W} \mathrm{m}^{-2}\right)$ & $\begin{array}{l}\text { Swiss Camp } \\
\text { JAR1 }\end{array}$ & $\begin{array}{l}-16 \\
-13\end{array}$ & $\begin{array}{l}-1 \\
-2\end{array}$ & $\begin{array}{r}5 \\
16\end{array}$ & $\begin{array}{l}21 \\
20\end{array}$ & $\begin{array}{l}0.95 \\
0.89\end{array}$ \\
\hline Sensible heat flux $\left(\mathrm{W} \mathrm{m}^{-2}\right)$ & $\begin{array}{l}\text { NASA-U } \\
\text { Humboldt } \\
\text { Tunu-N } \\
\text { DYE-2 } \\
\text { JAR1 } \\
\text { Saddle } \\
\text { NASA-E } \\
\text { CP2 } \\
\text { NGRIP }\end{array}$ & $\begin{array}{l}-27 \\
-28 \\
-20 \\
-19 \\
-21 \\
-12 \\
-20 \\
-27 \\
-23\end{array}$ & $\begin{array}{r}-23 \\
-3 \\
-1 \\
-18 \\
-12 \\
-5 \\
-17 \\
-16 \\
-11\end{array}$ & $\begin{array}{r}584 \\
14 \\
5 \\
1221 \\
129 \\
71 \\
591 \\
140 \\
88\end{array}$ & $\begin{array}{r}25 \\
15 \\
5 \\
19 \\
20 \\
8 \\
18 \\
20 \\
13\end{array}$ & $\begin{array}{l}0.71 \\
0.80 \\
0.89 \\
0.91 \\
0.40 \\
0.78 \\
0.48 \\
0.37 \\
0.88\end{array}$ \\
\hline Latent heat flux $\left(\mathrm{W} \mathrm{m}^{-2}\right)$ & $\begin{array}{l}\text { NASA-U } \\
\text { Humboldt } \\
\text { Summit } \\
\text { Tunu-N } \\
\text { DYE-2 } \\
\text { JAR1 } \\
\text { Saddle } \\
\text { South Dome } \\
\text { NASA-E } \\
\text { CP2 } \\
\text { NGRIP }\end{array}$ & $\begin{array}{r}2 \\
3 \\
-1 \\
1 \\
6 \\
13 \\
3 \\
6 \\
1 \\
5 \\
-1\end{array}$ & $\begin{array}{r}-2 \\
1 \\
-2 \\
0 \\
-1 \\
5 \\
0 \\
2 \\
0 \\
-1 \\
-2\end{array}$ & $\begin{array}{r}45 \\
54 \\
170 \\
16 \\
11 \\
55 \\
11 \\
56 \\
26 \\
14 \\
303\end{array}$ & $\begin{array}{l}3 \\
2 \\
2 \\
2 \\
3 \\
9 \\
2 \\
3 \\
1 \\
2 \\
2\end{array}$ & $\begin{array}{l}0.83 \\
0.99 \\
0.96 \\
0.91 \\
0.91 \\
0.20 \\
0.90 \\
0.89 \\
0.91 \\
0.96 \\
0.76\end{array}$ \\
\hline
\end{tabular}

ECHAM4 moisture exchange parameterizations over ice sheets (van den Broeke 1997).

\section{g. Sensitivity concerning the used Greenland topography}

After the bulk of this work was done, it became possible to make HIRHAM simulations with the accurate Ekholm Greenland elevation data. Therefore, for a sensitivity test, the 1998 annual cycle has been rerun using these new elevation data. Results from these simulations are provided as a basis to quantify the sensitivity of ice sheet climate simulations to large elevation biases. As seen from the elevation bias between the old (GTOPO30) and new (Ekholm) topography data (Fig. 2a, Table 2), one can expect improvements, particularly at high- and intermediate-elevation sites. Figure $2 \mathrm{~b}$ shows the changes in the simulated summer (June-August 1998) and winter (December 1997-February 1998) 2$\mathrm{m}$ temperatures over Greenland due to the different topographic datasets. As expected, the pattern in the temperature differences is strong when correlated with the elevation bias pattern, and shows that the temperatures are decreased by up to $3 \mathrm{~K}$ using the accurate elevation dataset. Figure 9 shows the temperature differences, HIRHAM with GTOPO30 elevation data minus HIRHAM with Ekholm elevation data, averaged over station sites in similar elevation regions. In fact, a marked improvement, that is, reduction in the warm bias is observed at high- and intermediate-elevation sites, where there was formerly a large elevation bias to correct. Surface air temperatures become cooler, and are closer to the observations. Given that the agreement is better and that smaller lapse-rate corrections are needed, including accurate elevation data greatly enhanced our confidence in HIRHAM simulations of Greenland's surface climate, as many of the monthly mean temperatures are within $1^{\circ}-2^{\circ} \mathrm{C}$ of the observations.

Given that albedo is parameterized in terms of temperature, sensitivity experiment albedos are somewhat smaller, although still too low by 0.04 in spring and up to 0.08 in midsummer. In the sensitivity run, where hyposmetric pressure corrections are less than $1-2 \mathrm{hPa}$, a smaller but consistent negative pressure bias is observed. The overestimated wind speed and apparently lacking surface drag in the model PBL become the most important remaining issues for HIRHAM model development.

\section{h. Model results in context of Greenland ice sheet mass balance}

Through validation, the HIRHAM model may be used to help quantify Greenland ice sheet mass balance variability. To provide a foundation for future mass balance studies using regional climate simulations, the present model representation of ice sheet energy and mass balance parameters is assessed for two full-year simulations, 1990 and 1998. Simulated annual-mean temperature distributions are presented in Fig. 10. According to data in Fig. 4, 1998 is a relatively warm year. As in Steffen and Box (2001) and the HIRHAM map, the $-20^{\circ} \mathrm{C}$ isotherm is much less pronounced in southern Greenland as compared to the temperature map for 1951-60 in Ohmura (1987). Compared to 1998, 1990 HIRHAM temperatures are warmer at the outermost 


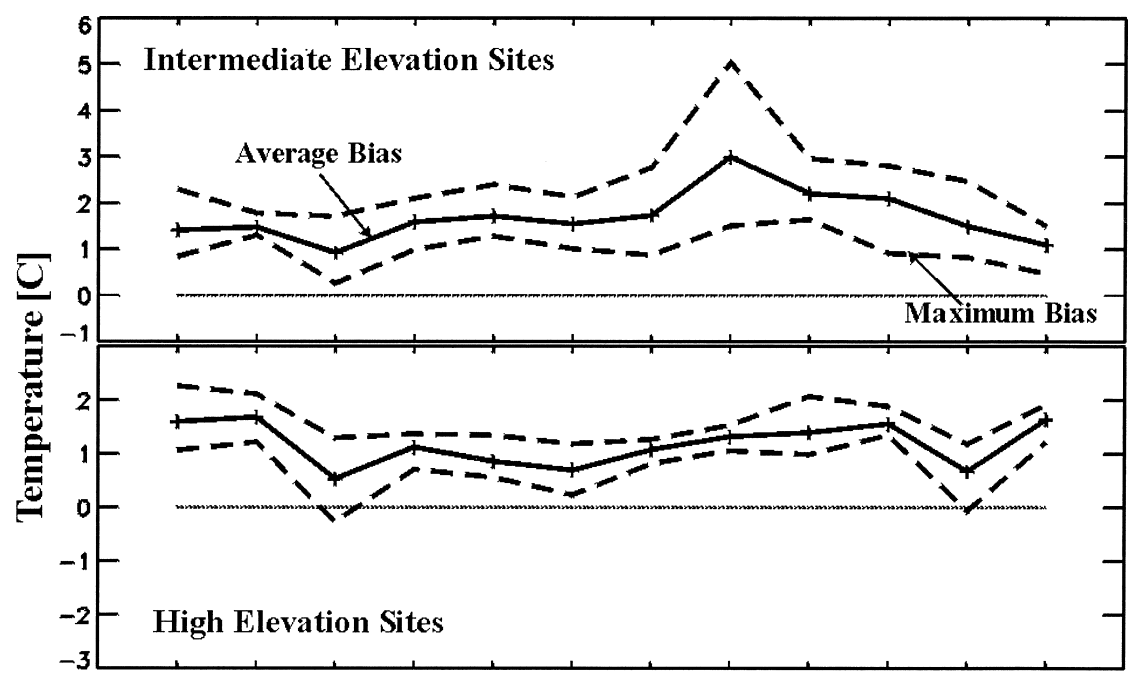

JAN FEB MAR APR MAY JUN JUL AUG SEP OCT NOV DEC

FIG. 9. Differences in simulated temperature for intermediate-elevation sites (NASA-U, NASAE, NASA-SE, GITS) and high-elevation sites (NGRIP, Summit, South Dome). The difference is between the HIRHAM simulation using the GTOPO30 topography and the simulation using the Ekholm topography.

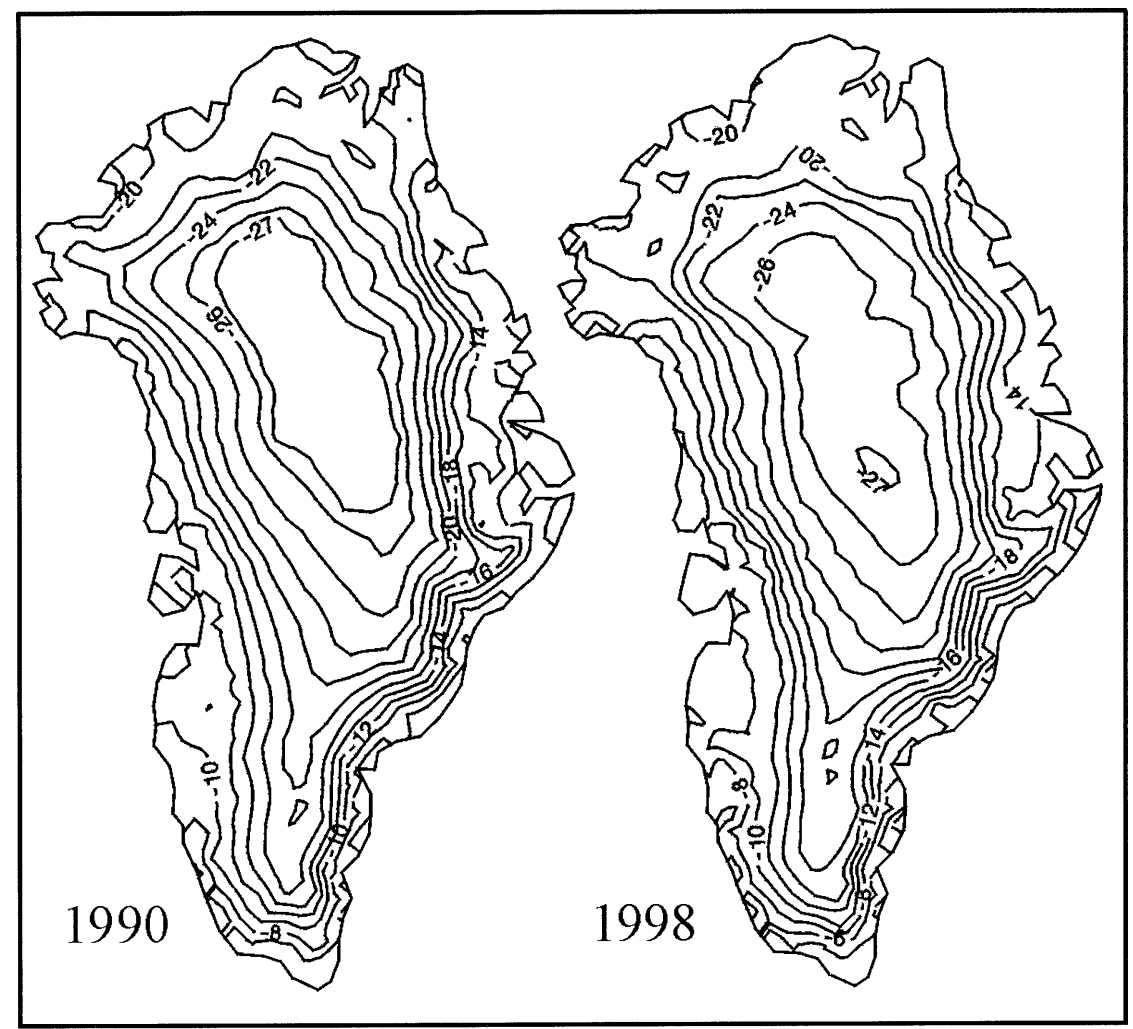

FIG. 10. Annual Greenland temperature maps for 1990 and 1998 based on the HIRHAM regional climate model. 


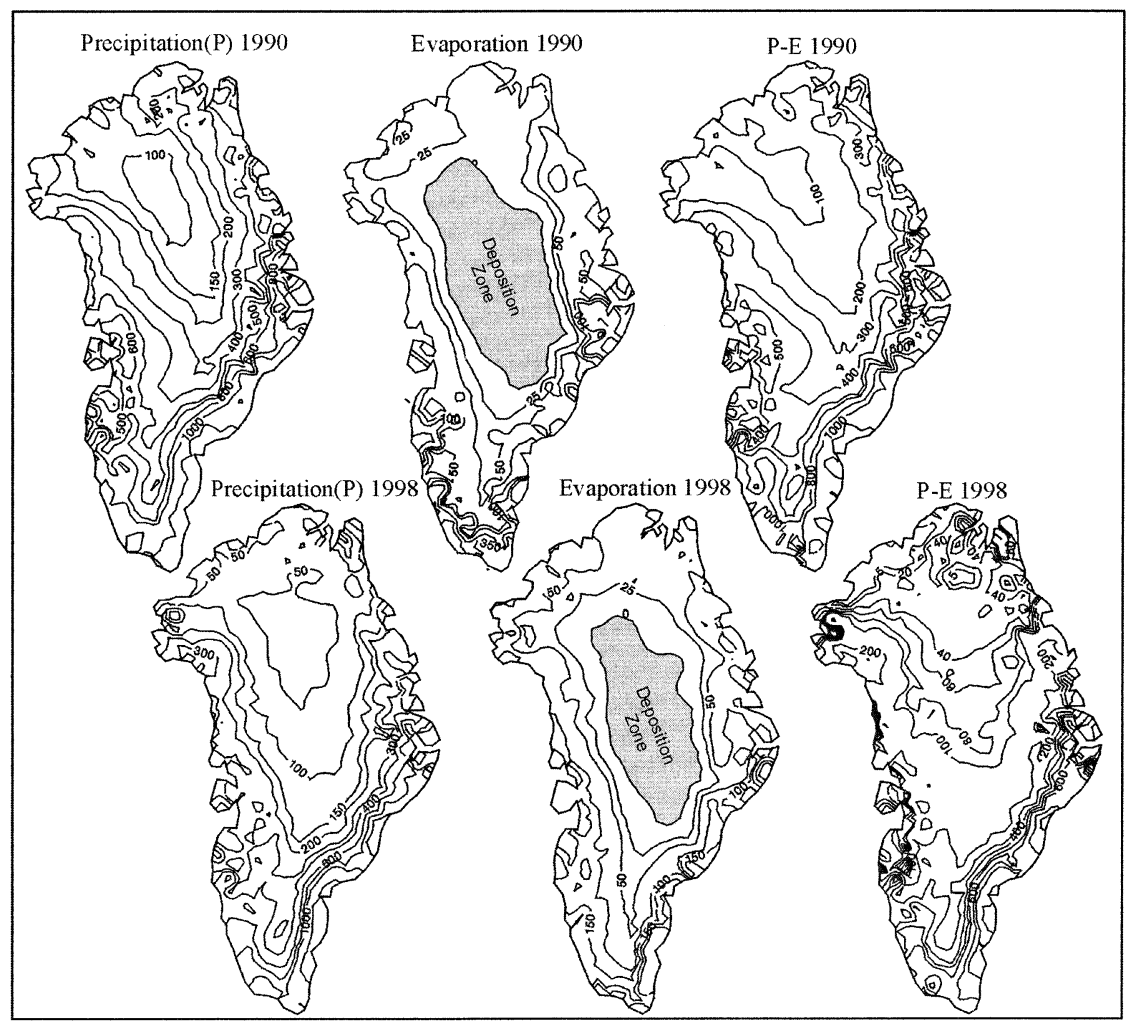

FIG. 11. Annual maps of Greenland ice sheet mass balance parameters (precipitation, evaporation, and accumulation) for 1990 and 1998 HIRHAM simulations. Units are $\mathrm{mm} \mathrm{yr}^{-1}$.

southwest coast, but colder in the interior. Regional variability is usually largely explained by circulation variability (Chen et al. 1997).

HIRHAM annual precipitation maps closely resemble those in Ohmura et al. (1999) and Bromwich et al. (2001b; Fig. 11). The spatial distribution of precipitation rate includes the precise and well known regional maximum in northwest Greenland, adjacent to Melville Bay, associated with Baffin Bay cyclone activity (Ohmura and Reeh 1991). Similarly, the regional precipitation minimum in the widest strip of land surrounding Sondrestrøm Fjord is represented in HIRHAM output. Maximum HIRHAM precipitation values in southeast Greenland (1500 $\left.\mathrm{mm} \mathrm{yr}^{-1}\right)$ compare closely with values in previous studies. The precipitation minimum at South Dome is consistent with the Ohmura et al. map. The most obvious difference between these distributions of precipitation is at the precipitation minimum in central and northern Greenland. HIRHAM precipitation is 50\% lower in central and northeast Greenland in 1998. Better agreement with the Ohmura et al. maps is observed for 1990. Expected large interannual variability is observed between 1990 and 1998 HIRHAM precipitation distributions. Comparing the precipitation map in the $2 \mathrm{yr}$, the general patterns persist, although interannual differences are large.

The precipitation $(P)$ map indicates lower values in central and northern Greenland as compared to Ohmura et al. (1999). But, compared with new estimates of the annual accumulation distribution over Greenland deduced from ice core parameters (Dethloff et al. 2002; Jung-Rothenhäusler et al. 2001, manuscript submitted to J. Glaciol.) the smaller accumulation in HIRHAM seems to be realistic.

The totals for precipitation, evaporation $(E)$, and $P$ - $E$ are made using the ice sheet area specified in Houghton et al. (2001), that is, $1.36 \times 10^{6} \mathrm{~km}^{2}$. HIRHAM precipitation is between $9 \%$ and $50 \%$ smaller than in Ohmura et al. (1999; Table 6). Evaporation is between $8 \%$ and 36\% smaller than in Ohmura et al. (1999) and Box and Steffen (2001). However, the agreement is within the uncertainty limits of the latter in situ method, reminding us of the need for increased accuracy of in situ methods. HIRHAM produces more evaporation in the warmer year (1998), consistent with the results from bulk formulations (Box and Steffen 2001). This is to be expected for bulk formulations, which are shown to underestimate water vapor deposition (van den Broeke 1997), while more accurate two-level in situ methods indicate that an offsetting increase in deposition rates may be expected given warmer conditions (Box and Steffen 2001).

\section{Conclusions}

A series of meaningful conclusions are drawn about HIRHAM model performance in comparison with data 
TABLE 6. Annual Greenland ice sheet mass balance components derived from the HIRHAM model in comparison with results from previous studies.

\begin{tabular}{lccc}
\hline \hline Quantity & Year & $\begin{array}{c}\text { Value } \\
\left(\times 10^{12} \mathrm{~kg}\right. \\
\left.\mathrm{yr}^{-1}\right)\end{array}$ & $\begin{array}{c}\text { Individual } \\
\text { studies }\end{array}$ \\
\hline Precipitation $(P)$ & 1990 & 535 & \\
& 1998 & 297 & $590^{*}$ \\
Evaporation $(E)$ & 1990 & 39 & \\
& 1998 & 56 & $61^{*}, 62 \pm$ \\
Accumulation $(P-E)$ & 1990 & 496 & $25^{* *}$ \\
& 1998 & 241 & \\
\hline
\end{tabular}

* Ohmura et al. (1999).

** Box and Steffen (2001).

from a network of 15 automatic weather stations distributed widely over the Greenland ice sheet. Systematic biases are identified based on comparisons for the 1998 annual cycle and for May-August simulations spanning 1991-98. A series of biases stem from an average -180-m elevation bias in the GTOPO30 elevation data over Greenland. When the ice sheet elevation is simulated to be lower than in reality, surface air temperatures are warmer than observed. Other biases arise from the temperature bias. Albedo, which is parameterized in terms of temperature, becomes negatively biased. Negatively biased surface albedo leads to greater than observed net shortwave flux and, as a result, an inaccuracy in the radiation and energy balance. Negative elevation bias leads to a positive surface pressure bias. In a sensitivity run it is clearly shown that the surface climate variables improve by using the more accurate Ekholm Greenland elevation data. The positive surface pressure bias and positive near-surface temperature bias are decreased. Consequently, the albedo and surface radiative and turbulent fluxes are slightly improved.

Other biases, seemingly unrelated to elevation bias were also identified. Incoming shortwave irradiance is $20 \%-60 \%$ less than in the observations, implying that modeled cloud amount is probably too high. However, this bias may be due to other model errors besides an overprediction of cloud amount. Unfortunately, for this study there are no observational cloud data available for ice sheet locations that coincide with the model period. Surface turbulent heat fluxes are greater in the model than in the observations. Overestimated sensible heat fluxes are caused, in part, by the model warm bias, and too great wind speeds. The overestimated wind speed and apparently lacking surface drag in the model PBL become the most important remaining issues for HIRHAM model development.

Another basic problem became clear when comparing accurate station elevations with a relatively coarse regional model grid. Even over a relatively smooth surface such as the Greenland ice sheet, the existence of un- dulations, particularly in the relatively steep lower elevations, will make it impossible, in most cases, for the elevations of point measurements to match with a relatively coarse grid. Therefore, even the use of an accurate elevation dataset over model resolution exceeding the undulation scale, there will be some disagreement between the model and observations that is not caused by physical model error, but the difference in elevation from a specific point and an average area. Therefore, it must be kept in mind that the envelope of uncertainty in a comparison between station observations and a regional model is bound not only by model and observational error, but in spatial sampling by the model and observations. In this context, it comes as little surprise that there is better model performance at high elevations where the topography is flat.

Based on the results of these comparisons, the following model improvements are recommended as requirements for any regional climate simulation of Greenland: (i) the use of an accurate ice sheet topographic dataset; (ii) accurate albedo parameterization, (iii) more realistic surface-layer model, including the thermal conductivity for snow/firn; (iv) accurate PBL momentum exchange.

During monthly or 1-yr-long simulations as in this study, random errors are not averaged out. Therefore, future work will involve multiannual, ensemble simulations, including further validation with in situ observations. Within this framework, the presented comparison demonstrates that the HIRHAM regional climate model can be a useful tool for ice sheet mass balance studies and ice core interpretation.

Acknowledgments. The intellectual support of $\mathrm{K}$. Dethloff and K. Steffen have been of great assistance during this study. This study has been facilitated by the strategy fund project "Natural climate variations from 10,000 years BP to the present day (KIHZ)" of the Helmholtz Association of German Research Centres. The NASA Polar Oceans Division has funding the GCNet. NSF OPP has sponsored two AWS sites in the north of Greenland and indirectly supports the GC-Net through C130 flights to DYE-2, NGRIP, and Summit. A significant part of the revision of this work was performed at the Cooperative Institute for Research in Environmental Sciences in Boulder, Colorado. We are grateful to $\mathrm{H}$. Deckelmann and I. Hebestadt for computing assistance. Critical insight from two reviewers was very helpful in the final preparation of this work.

\section{REFERENCES}

Bamber, J., S. Ekholm, and W. B. Krabill, 2001: A new, high-resolution digital elevation model of Greenland fully validated with airborne laser altimeter data. J. Geophys. Res., 106, 33 773-33 780.

Barry, R. G., and G. N. Kiladis, 1982: Climatic characteristics of Greenland. Climatic and Physical Characteristics of the Greenland Ice Sheet, U. Radok, Ed., CIRES, 7-33.

Box, J. E., and K. Steffen, 2001: Sublimation estimates for the Green- 
land ice sheet using automated weather station observations. $J$. Geophys. Res., 106, 33 965-33981.

Brinkop, S., and E. Roeckner, 1995: Sensitivity of a general circulation model to parameterizations of cloud-turbulence interactions in the atmospheric boundary layer. Tellus, 47A, 197-220.

Bromwich, D. H., J. Cassano, T. Klein, G. Heinemann, K. Hines, K. Steffen, and J. Box, 2001a: Mesoscale modeling of katabatic winds over Greenland with the Polar MM5. Mon. Wea. Rev., 129, 2290-2309.

- Q.-S. Chen, L.-S. Bai, E. Cassano, and Y. Li, 2001b: Modeled precipitation variability over the Greenland Ice Sheet. J. Geophys. Res., 106, 33 891-33908.

Cassano, J., J. E. Box, D. Bromwich, L. Li, and K. Steffen, 2001: Evaluation of polar MM5 simulations of Greenland's atmospheric circulation. J. Geophys. Res., 106, 33 867-33 889.

Chen, Q. S., D. H. Bromwich, and L. Bai, 1997: Precipitation over Greenland retrieved by a dynamic method and its relation to cyclonic activity. J. Climate, 10, 839-870.

Christensen, J. H., and P. Kuhry, 2000: High resolution regional climate model validation and permafrost simulation for the EastEuropean Russian Arctic. J. Geophys. Res., 105, 29 647-29 658.

—-, O. B. Christensen, P. Lopez, E. van Meijgaard, and M. Botzet, 1996: The HIRHAM4 regional atmospheric climate model. DMI Scientific Rep. 96-4, Danish Meteorological Institute, Copenhagen, Denmark, $51 \mathrm{pp}$.

Christensen, O. B., J. H. Christensen, B. Machenhauer, and M. Botzet, 1998: Very high-resolution regional climate simulations over Scandinavia-Present climate. J. Climate, 11, 3204-3229.

Cuffey, K. M., and S. J. Marshall, 2000: Substantial contribution to sea-level rise during the last interglacial from the Greenland ice sheet. Nature, 404, 591-594.

Cullen, N., and K. Steffen, 2001: Unstable near-surface boundary conditions in summer on top of the Greenland Ice Sheet. Geophys. Res. Lett., 28, 4491-4494.

de Elía, R., R. Laprise, and B. Denis, 2002: Forecasting skill limits of nested limited-area models: A perfect-model approach. Mon. Wea. Rev., 130, 2006-2023.

Dethloff, K., A. Rinke, R. Lehmann, J. Christensen, M. Botzet, and B. Machenhauser, 1996: Regional climate model of the Arctic atmosphere. J. Geophys. Res., 101, 23 401-23 422.

- C. Abegg, A. Rinke, I. Hebestadt, and V. Romanov, 2001: Sensitivity of arctic climate simulations to different boundary layer parameterizations in a regional climate model. Tellus, 53A, $1-26$.

— and Coauthors, 2002: Recent Greenland accumulation estimated from regional climate model simulations and ice core analysis. J. Climate, 15, 2821-2832.

DKRZ, 1992: The ECHAM3 atmospheric general circulation model. Tech. Rep. 6, Deutsches Klimarechenzentrum, Hamburg, Germany, 184 pp.

Dorn, W., K. Dethloff, A. Rinke, and M. Botzet, 2000: Distinct circulation states of the Arctic atmosphere induced by natural climate variability. J. Geophys. Res., 105, 29 659-29 668.

Ekholm, S., 1996: A full coverage, high-resolution, topographic model of Greenland computed from a variety of digital elevation data. J. Geophys. Res., 101, 21 961-21 972.

Gesch, D. B., 1994: Topographic data requirements for EOS global change research. U.S. Geological Survey Open-File Rep. 94 626, $60 \mathrm{pp}$.

__ , and K. S. Larson, 1996: Techniques for development of global 1-kilometer digital elevation models. Proceedings Pecora Thirteen Computer File: Human Interactions with the Environment: Perspectives from Space, Asprs Pubns.

Giorgi, F., and X. Bi, 2000: A study of internal variability of a regional climate model. J. Geophys. Res., 105, 29 503-29 521.

Hagemann, S., M. Botzet, L. Dümenil, and B. Machenhauer, 1999: Derivation of global GCM boundary conditions from $1 \mathrm{~km}$ land use satellite data. MPI Rep. 289, Max Planck Institute, Hamburg, Germany, $34 \mathrm{pp}$.

Hanna, E., and P. Valdes, 2001: Validation of ECMWF (re)analysis surface climate data, 1979-1998, 2001: for Greenland and implications for mass balance modelling of the ice sheet. Int. J. Climatol., 21, 171-195.

Haugen, J. E., D. Bjørge, and T. E. Nordeng, 1999: A 20 year climate change experiment with HIRHAM, using MPI boundary data. RegClim General Tech. Rep. 1, 37-43, Kjeller, Norway, 130 pp.

Houghton, J. T., Y. Ding, D. J. Griggs, M. Noguer, P. van der Linden, X. Dai, and K. Maskell, Eds., 2001: Climate Change 2001: The Scientific Basis: Contribution of Working Group I to the Third Assessment Report of the Intergovernmental Panel on Climate Change. Cambridge University Press, 944 pp.

Jones, R. G., J. M. Murphy, and M. Nouger, 1995: Simulation of climate change over Europe using a nested regional climate model. Part I. Assessment of control climate including sensitivity to location of lateral boundaries. Quart. J. Roy. Meteor. Soc., 121, 1413-1449.

Klein, T., G. Heinemann, D. H. Bromwich, J. J. Cassano, and K. M. Hines, 2001: Mesoscale modeling of katabatic winds over Greenland and comparisons with AWS and aircraft data. J. Meteor. Atmos. Phys., 78, 115-132.

Krinner, G., and C. Genthon, 1999: Altitude dependence of the ice sheet surface climate. Geophys. Res. Lett., 26, 2227-2230.

Kristjánsson, J. E., and H. McInnes, 1999: The impact of Greenland on cyclone evolution in the North Atlantic. Quart. J. Roy. Meteor. Soc., 125, 2819-2834.

Noguer, M., R. Jones, and J. Murphy, 1998: Sources of systematic error in the climatology of a regional climate model over Europe. Climate Dyn., 14, 691-712.

Ohmura, A., 1987: New temperature distribution maps for Greenland. Z. Gletscherkd. Glazialgeol., 23, 1-45.

_ for Greenland. J. Glaciol., 37, 140-148.

_ , and Coauthors, 1991: ETH Greenland Expedition I, progress report no. 1, April 1989 to February, 1991. Tech. Report, Department of Geography, ETH Zürich, 108 pp.

_ , and Coauthors, 1992: ETH Greenland Expedition II, progress Rep. 2, April 1991 to October, 1992. Tech. Report, Department of Geography, ETH Zürich, 94 pp.

_- M. Wild, and L. Bengtsson, 1996: A possible change in mass balance of Greenland and Antarctica in the coming century. $J$. Climate, 9, 2124-2135.

_, P. Calanca, M. Wild, and M. Anklin, 1999: Precipitation, accumulation, and mass balance of the Greenland ice sheet. $Z$. Gletscherkd. Glazialgeol., 35, 1-20.

Pan, Z., J. H. Christensen, R. W. Arritt, W. J. Gutowski Jr., and E. S. Takle, 2000: Ten-year U.S. regional climate simulations for impact assessments. Preprints, 11th Symp. on Global Change Studies, Long Beach, CA, Amer. Meteor. Soc., 24-31.

Reeh, N., 1999: Mass balance of the Greenland ice sheet: Can modern observations reduce the uncertainty? Geografis. Ann., 81A, 735742.

Rinke, A., and K. Dethloff, 2000: On the sensitivity of a regional Arctic climate model to initial and boundary conditions. Climate Res., 14, 101-113.

- — - J. J. H. Christensen, M. Botzet, and B. Machenhauer, 1997: Simulation and validation of Arctic radiation and clouds in a regional climate model. J. Geophys. Res., 102, 29 833-29 847. ,$- \ldots$, and — 1999a: Arctic winter climate and its interannual variations simulated by a regional climate model. J. Geophys. Res., 104, 19 027-19038.

— _ — - A. Spekat, W. Enke, and J. H. Christensen, 1999b: High resolution climate simulations over the Arctic. Polar Res., 18, $1-9$.

- A. H. Lynch, and K. Dethloff, 2000: Intercomparison of Arctic regional climate simulations: Case studies of January and June 1990. J. Geophys. Res., 105, 29 669-29 683.

Robock, A., 1980: The seasonal cycle of snow cover, sea ice, and surface albedo. Mon. Wea. Rev., 108, 267-285.

Roeckner, E., and Coauthors, 1996: The atmospheric general circulation model ECHAM-4: Model description and simulation of 
present-day climate. Rep. 218, Max Plank Institut, Hamburg, Germany, 90 pp.

Shuman, C. A., K. Steffen, J. E. Box, and C. R. Stearns, 2001: A dozen years of temperature observations at the summit: Central Greenland automatic weather stations 1987-1999. J. Appl. Meteor., 40, 741-752.

Stearns, C. R., and G. A. Weidner, 1991: The polar automatic weather station project of the University of Wisconsin. Proc. Int. Conf. on the Role of the Polar Regions in Global Change, Fairbanks, AK, 58-62.

Steffen, K., and T. deMaria, 1996: Surface energy fluxes of arctic winter sea ice in Barrow Strait. J. Appl. Meteor., 35, 2067-2079.

_ Sheet: Greenland climate network 1995-1999. J. Geophys. Res., 106, 33 951-33 964

_ _ _ , and W. Abdalati, 1996: Greenland Climate Network: GC-
Net, Special report on Glaciers, Ice Sheets, and Volcanoes. Rep. 96-27, Cold Regions Research and Engineering Laboratory, Hanover, NH, 98-103.

Thompson, S. L., and D. Pollard, 1997: Greenland and Antarctic mass balance for present and doubled atmospheric $\mathrm{CO}_{2}$ from the GENESIS version-2 global climate model. J. Climate, 10, 871-900.

van den Broeke, M. R., 1997: Spatial and temporal variation of sublimation on Antarctica: Results of a high-resolution general circulation model. J. Geophys. Res., 102, 29 765-29 777.

van Lipzig, N. P. M., E. van Meijgaard, and J. Oerlemans, 1999: Evaluation of a regional atmospheric model using measurements of surface heat exchange processes from a site in Antarctica. Mon. Wea. Rev., 127, 1994-2011.

Walsh, J. E., V. M. Kattsov, W. L. Chapman, V. Govorkova, and T. Pavlova, 2002: Comparison of Arctic climate simulations by uncoupled and coupled global models. J. Climate, 15, 14291446. 
Copyright $\odot 2003$ EBSCO Publishing 